\title{
Millennial-scale fluctuations of the European Ice Sheet at the end of the last glacial, and their potential impact on global climate
}

\author{
Toucanne Samuel ${ }^{1,{ }^{*}}$, Soulet Guillaume ${ }^{2}$, Freslon Nicolas ${ }^{1}$, Silva Jacinto Ricardo ${ }^{1}$, \\ Dennielou Bernard ${ }^{1}$, Zaragosi Sébastien ${ }^{3}$, Eynaud Frédérique ${ }^{3}$, Bourillet Jean-Francois ${ }^{1}$, \\ Bayon Germain ${ }^{1}$ \\ ${ }^{1}$ Institut Français de Recherche pour l'Exploitation de la Mer (IFREMER), Unité de Recherche \\ Géosciences Marines, F-29280 Plouzané, France \\ ${ }^{2}$ Woods Hole Oceanographic Institution (WHOI), Department of Geology and Geophysics, MA 02543 , \\ ${ }^{3}$ Université de Bordeaux, UMR-CNRS 5805 EPOC, F-33405 Talence, France
} USA

Corresponding author : Samuel Toucanne, email address : stoucann@ifremer.fr

\begin{abstract}
:
Reconstructing Northern Hemisphere ice-sheet oscillations and meltwater routing to the ocean is important to better understand the mechanisms behind abrupt climate changes. To date, research efforts have mainly focused on the North American (Laurentide) ice-sheets (LIS), leaving the potential role of the European Ice Sheet (EIS), and of the Scandinavian ice-sheet (SIS) in particular, largely unexplored. Using neodymium isotopes in detrital sediments deposited off the Channel River, we provide a continuous and well-dated record for the evolution of the EIS southern margin through the end of the last glacial period and during the deglaciation. Our results reveal that the evolution of EIS margins was accompanied with substantial ice recession (especially of the SIS) and simultaneous release of meltwater to the North Atlantic. These events occurred both in the course of the EIS to its LGM position (i.e., during Heinrich Stadial -HS- 3 and HS2; 31-29 ka and 26-23 ka, respectively) and during the deglaciation (i.e., at $\sim 22 \mathrm{ka}, \sim 20-19 \mathrm{ka}$ and from $18.2 \pm 0.2$ to $16.7 \pm 0.2 \mathrm{ka}$ that corresponds to the first part of HS1). The deglaciation was discontinuous in character, and similar in timing to that of the southern LIS margin, with moderate ice-sheet retreat (from $22.5 \pm 0.2 \mathrm{ka}$ in the Baltic lowlands) as soon as the northern summer insolation increase (from $\sim 23 \mathrm{ka}$ ) and an acceleration of the margin retreat thereafter (from $\sim 20 \mathrm{ka}$ ). Importantly, our results show that EIS retreat events and release of meltwater to the North Atlantic during the deglaciation coincide with AMOC destabilisation and interhemispheric climate changes. They thus suggest that the EIS, together with the LIS, could have played a critical role in the climatic reorganization that accompanied the last deglaciation. Finally, our data suggest that meltwater discharges to the North Atlantic produced by large-scale recession of continental parts of Northern Hemisphere ice sheets during HS, could have been a possible source for the oceanic perturbations (i.e., AMOC shutdown) responsible for the marine-based ice stream purge cycle, or socalled HE's, that punctuate the last glacial period.
\end{abstract}


Keywords : European ice-sheet, Channel River, Meltwater, Deglaciation, Neodymium, Termination

\section{Highlights}

- Nd isotope evidence for sources of Channel River meltwater discharges. Meltwater discharges caused by recession of the EIS into the North European Plain. Timing of runoff pulses provide new insights into EIS history. Temporal match between runoff pulses and AMOC shutdown reveals the role of the EIS in past global climate changes. 


\section{INTRODUCTION}

54

A central question of climate sciences is the understanding of the causes of the Pleistocene ice ages, and of the rapid collapse of ice-sheets (i.e., 'terminations'; see Paillard, 2015 for a thorough review). The emergent 'termination paradigm' posits that the necessary condition to drive the earth out of ice ages is the occurrence of a single (Terminations II and IV) or series (Terminations I and III) of multi-millennial climatic oscillations involving variations in the strength of Atlantic Meridional Oceanic Circulation (AMOC) (Barker et al., 2011; Broecker et al., 2010; Cheng et al., 2009; Denton et al., 2010; Ruddiman et al., 1980). These long-lived AMOC slowdowns would have led to prolonged stadial conditions in the Northern Hemisphere $(\mathrm{NH})$, Southern Hemisphere $(\mathrm{SH})$ warming, and $\mathrm{CO}_{2}$ degassing from the Southern Ocean, in turn amplifying global deglacial warming (Barker et al., 2009; Cheng et al., 2009; Denton et al., 2010; Shakun et al., 2012). Thus, the 'termination paradigm' implies that the primary condition required to trigger a termination is not solely the magnitude of the boreal insolation change but also a sufficient volume of freshwater released into the North Atlantic that can perennially weaken the AMOC. The only available reservoir for such large volumes of fresh water was the extensive and isostatically-depressed Laurentide (LIS) and European (EIS) ice-sheets that achieved maxima on both sides of the North Atlantic at the end of each ice age. However, the potential sources of such prolonged events of freshwater release and any associated AMOC reduction are still uncertain due to the difficulties to connect continental ice-sheet fluctuations and associated meltwater releases to paleoclimatic and paleoceanographic records (e.g., Broecker, 2006). In the specific case of the last Termination ( $\sim 19$ to $10 \mathrm{ka}$; Clark et al., 2012c), the first prolonged event of AMOC reduction is thought to have occurred between $\sim 18$ and 15 ka (Hall et al., 2006; McManus et al., 2004), corresponding to Heinrich Stadial 1 (HS1). Evidence from the southern LIS margin and the 
western North Atlantic suggest that the LIS could have provided substantial freshwater during this interval (Clark et al., 2004a; Clark et al., 2007; Clark et al., 2001), as well as during the subsequent prolonged AMOC slowdown that occurred during the Younger Dryas cold event (Broecker et al., 1988; Carlson et al., 2007; Clark et al., 2004a; Clark et al., 2007; Clark et al., 2001). The meltwater contribution of the EIS remains largely unknown in comparison. Substantial hydrographic changes have been reported along the European margin at times of AMOC perturbations including HS1, thus pointing out the possible participation of the EIS to these events (Eynaud et al., 2012; Hall et al., 2011; Hall et al., 2006; Knutz et al., 2007; Lekens et al., 2006; McCabe and Clark, 1998; Peck et al., 2006; Peck et al., 2007; Scourse et al., 2000). However, our understanding remains incomplete since the correlation of EIS fluctuations with these paleoceanographic changes and with well-dated proxy records for AMOC variability only relate to the marine ice-streams and ice-shelves draining into the North Atlantic (e.g., Peck et al., 2006). In contrast, the correlation with the evolution of the major terrestrial ice-streams in the southern EIS (e.g., southern Baltic ice stream complex), known to be very active due to melting bed conditions (Boulton et al., 2001; Boulton et al., 1985), is poorly documented (Lehman et al., 1991; Rinterknecht et al., 2006). In addition, hosing experiments demonstrate that the sensitivity of ocean circulation depends on the location of the freshwater perturbation and that the climate system is very sensitive to freshwater perturbations originating from the European margin (Roche et al., 2010). Finally, just as the LIS, the EIS had reached its maximum extent during the Last Glacial Maximum (LGM, 26-19 ka; Clark et al., 2009), making it a potential source of freshwater at the end of the last ice age. This leads to the possibility that the EIS might have played a significant role in the first steps of the last termination.

The EIS, composed of the British-Irish (BIIS) and the Scandinavian (SIS) ice sheets, formed the second largest NH ice mass (Fig. 1). The two regional ice-sheets merged during the last 
103 glacial (Bradwell et al., 2008; Carr et al., 2000; Sejrup et al., 2009), covering the North Sea

104 area and leading to the formation of a large river system that drained the western European

105 continent (Gibbard, 1988; Toucanne et al., 2009b; Toucanne et al., 2010). During glacial

106 times, the so-called Channel River routed substantial amounts of meltwater to the North

107 Atlantic (Eynaud et al., 2007; Ménot et al., 2006; Roche et al., 2010; Toucanne et al., 2010;

108 Zaragosi et al., 2001). To explore the potential role of the EIS during the last termination, we

109 investigate the link between the EIS ice-margin fluctuations, Channel River meltwater 110 discharge, and AMOC rate. Our results provides direct evidence that the EIS played a crucial

111 role in the abrupt reorganizations of the global climate system that accompanied the end of 112 the last glacial period.

\section{MATERIAL AND METHODS}

We focus on core MD95-2002, a sedimentary archive recovered directly off the mouth of the

117 Channel River (Meriadzek Terrace; 2, $174 \mathrm{~m}$ water depth; 47'27 $\mathrm{N}, 8^{\prime} 32^{\circ} \mathrm{W}$ ) (Fig. 1). Previous

118 studies have shown that core MD95-2002 is suitable for reconstructing the deglacial pulses of

119 meltwater emanating from the EIS (Eynaud et al., 2012; Eynaud et al., 2007; Ménot et al.,

120 2006; Toucanne et al., 2009a; Toucanne et al., 2010; Zaragosi et al., 2001). To decipher the

121 coupling between EIS ice-margin fluctuations and Channel River meltwater discharge, we

122 measured $\mathrm{Nd}$ isotope ratios of fine-grained detrital fraction from this core $(n=95)$. The

123 neodymium isotopic composition $\left(\varepsilon_{\mathrm{Nd}}\right)$ of terrigenous sediment is a powerful tracer for

124 geographical provenance because the $\varepsilon_{\mathrm{Nd}}$ signature of detrital sediment is retained during

125 continental weathering and subsequent transport (Goldstein and Jacobsen, 1988). Considering

126 that clays and silts are the dominant size-fractions transported to the sea by meltwaters

127 emanating from ice-margins (e.g. Brown and Kennett, 1998), we focused our analyses on the 
128 clay-silt fraction $(<63 \mu \mathrm{m})$ of the MD95-2002 samples. In order to link the observed $\varepsilon_{\mathrm{Nd}}$

129 changes to potential source regions, a series of 45 LGM glacigenic samples from moraines,

130 ice-marginal valleys and proglacial lakes alongside the EIS southern margin and a suite of 33

131 modern sediments recovered from the mouth (i.e., mudflats, delta, bays, lagoons) of various

132 European rivers were analysed (Fig. 1), focusing on the clay-silt fraction for comparison with

133 the MD95-2002 samples. Fine-grained river sediments integrate the geochemical diversity of

134 catchment areas, and as such can provide a reliable average $\mathrm{Nd}$ isotopic composition of their

135 corresponding drainage basin (Goldstein and Jacobsen, 1988).

136 Dried fine-grained fractions (typically $\sim 0.5 \mathrm{~g}$ ) were crushed using an agate mortar and pestle.

137 The terrigenous fraction of each sediment sample was digested by alkaline fusion (Bayon et 138 al., 2009) after removal of all carbonate, Fe-Mn oxyde and organic components using a 139 sequential leaching procedure (Bayon et al., 2002). Prior to analyses, the Nd fractions were 140 isolated by ion chromatography (see details in Bayon et al., 2012). Isotopic measurements 141 were performed at the Pôle Spectrométrie Océan, Brest (France), using a Thermo Scientific 142 Neptune multi-collector ICPMS. Mass bias corrections on Nd were made with the exponential 143 law, using ${ }^{146} \mathrm{Nd} /{ }^{144} \mathrm{Nd}=0.7219 . \mathrm{Nd}$ isotopic compositions were determined using sample144 standard bracketing, by analysing JNdi-1 standard solutions every two samples. Mass-bias 145 corrected values for ${ }^{143} \mathrm{Nd} /{ }^{144} \mathrm{Nd}$ were normalized to a $\mathrm{JNdi}-1$ value of ${ }^{143} \mathrm{Nd} /{ }^{144} \mathrm{Nd}=0.512115$

146 (Tanaka et al., 2000). Replicate analyses of the JNdi-1 standard solution during the course of 147 this study gave ${ }^{143} \mathrm{Nd} /{ }^{144} \mathrm{Nd}=0.512095 \pm 0.000009(2 \mathrm{SD}, n=150)$, which corresponds to an 148 external reproducibility of $\sim \pm 0.3 \varepsilon$-units, taken as the estimated uncertainty on our 149 measurements. In this study, both measured ${ }^{143} \mathrm{Nd} /{ }^{144} \mathrm{Nd}$ ratios and literature data are reported 150 in $\varepsilon_{\mathrm{Nd}}$ notation, $\left[\left({ }^{143} \mathrm{Nd} /{ }^{144} \mathrm{Nd}\right)_{\text {sample }}\left(\left(^{143} \mathrm{Nd} /{ }^{144} \mathrm{Nd}\right)_{\mathrm{CHUR}}-1\right] \times 10^{4}\right.$, using $\left({ }^{143} \mathrm{Nd} /{ }^{144} \mathrm{Nd}\right)_{\mathrm{CHUR}}=$ 1510.512638 (Jacobsen and Wasserburg, 1980). 
152 Finally, the bulk intensity of major elements for core MD95-2002 was analyzed using an

153 Avaatech X-Ray Fluorescence (XRF) core scanner at the Institut Français de Recherche pour 154 l'Exploitation de la Mer (IFREMER), Brest (France). XRF data were measured every 10mm 155 along the entire length of the core, with a count time of 10 seconds, by setting the voltage to $15610 \mathrm{kV}$ (no filter) and $30 \mathrm{kV}$ (Pd thick filter) and the intensity to $600 \mathrm{~mA}$ and $1000 \mathrm{~mA}$, 157 respectively. The same methodology was used to analyse the bulk intensity of major elements 158 of cores MD03-2690 and MD03-2695 (Armorican turbidite system; Toucanne et al., 2008) 159 (see Fig. 1 for location). Only data for Titanium (Ti), Iron (Fe) and Calcium (Ca) are reported 160 in this study. It is commonly assumed that $\mathrm{Ti}$ and Fe elements are related to terrigenous161 siliciclastic components (clays, heavy minerals), while $\mathrm{Ca}$ mainly reflects the marine 162 carbonate content (calcite and aragonite) in the sediment (Richter et al., 2006). Therefore the 163 ratios of XRF intensities of $\mathrm{Ti}$ and $\mathrm{Ca}(\mathrm{Ti} / \mathrm{Ca})$ and $\mathrm{Fe}$ and $\mathrm{Ca}(\mathrm{Fe} / \mathrm{Ca})$ were previously used to 164 estimate terrigenous inputs on continental margins, and by extension past river runoff (e.g., 165 Arz et al., 1998; Jennerjahn et al., 2004; Toucanne et al., 2009a; Ziegler et al., 2013).

3. MD95-2002 CORE CHRONOLOGY

169 The chronostratigraphic framework of core MD95-2002 is based on 22 monospecific ${ }^{14} \mathrm{C}$ ages 170 [performed on Globigerina bulloides and Neogloboquadrina pachyderma (left coiling) from

171 the $>150 \mu \mathrm{m}$ fraction] and 4 additional ${ }^{14} \mathrm{C}$ ages from nearby cores MD03-2692 (Trevelyan 172 Escarpment; Eynaud et al., 2007; Mojtahid et al., 2005) and MD03-2690 (Armorican turbidite 173 system; Toucanne et al., 2008) (Figs 2, 3 and 4; Table 1). The cores were synchronized by 174 means of their XRF-Ti/Ca records with an estimated error of less than $10 \mathrm{~cm}$ (Fig. 2). 175 Additional control-points were added to the age model by tuning the $N$. pachyderma 176 abundance to the NGRIP ice core $\delta^{18} \mathrm{O}$ record (GICC05 timescale; Andersen et al., 2006) 
177 (Table 1). To do so, we assumed that abrupt changes in the $N$. pachyderma abundance

178 (interpreted as latitudinal migration of the polar front) were coeval to the sharp changes in

179 Greenland air temperature (Bond et al., 1993; Eynaud et al., 2012; Scourse et al., 2009;

180 Zaragosi et al., 2001). ${ }^{14} \mathrm{C}$ ages were first corrected for reservoir age and then calibrated to

181 calendar age using the IntCal13 calibration curve (Reimer et al., 2013). The current regional

182 reservoir age is $352 \pm 92{ }^{14} \mathrm{C}$ years (average of the reservoir ages reported for the 100

183 locations closest to MD95-2002 site; http://www.calib.qub.ac.uk/marine). However, the

184 regional reservoir age has changed through time (Stern and Lisiecki, 2013). Prior to HS1 and

185 during the Holocene, reservoir age was almost constant and centred on $\sim 400 \pm 200{ }^{14} \mathrm{C}$ years.

186 During HS1, the Bølling-Allerød (BA) and the Younger Dryas, average reservoir ages were 187970,680 and $875{ }^{14} \mathrm{C}$ years with a typical uncertainty of $200{ }^{14} \mathrm{C}$ years $(1 \sigma)$. All these climatic 188 events are easily identifiable owing to MD95-2002 left coiling $N$. pachyderma stratigraphy 189 (Eynaud et al., 2012; Zaragosi et al., 2001). Thus, ${ }^{14} \mathrm{C}$ ages from each stratigraphic unit were 190 corrected for the ad hoc reservoir age and uncertainty was propagated through the quadratic 191 sum (Table 1). The comparison of NGRIP and the $N$. pachyderma stratigraphy at the HS1/BA 192 transition illustrates the suitability of the applied reservoir correction. Indeed, the abrupt 193 decrease in $N$. pachyderma abundance between $380 \mathrm{~cm}\left[13,020 \pm 60{ }^{14} \mathrm{C}\right.$ years before present 194 (BP); Table 1] and $390 \mathrm{~cm}\left(13,170 \pm 70{ }^{14} \mathrm{C}\right.$ years BP) in MD95-2002 corresponds to the BA 195 NGRIP's sharp increase in air temperature dated to $14,640 \pm 90$ calendar years BP (Andersen 196 et al., 2006). This corresponds to $12,460 \pm 40{ }^{14} \mathrm{C}$ years $\mathrm{BP}$ according to the IntCal13 197 calibration curve. This leads to reservoir ages of $560 \pm 70$ and $710 \pm 80{ }^{14} \mathrm{C}$ years for depths 198380 and $390 \mathrm{~cm}$, respectively. These values are statistically indistinguishable from the $680 \pm$ $199200{ }^{14} \mathrm{C}$ years (Stern and Lisiecki, 2013) reservoir correction applied. The final age model was 200 performed using the age modelling software Clam (Blaauw, 2010; version 2.2) and reported 201 with 95\% confidence intervals (Fig. 3). The additional control-points obtained from the $N$. 
pachyderma $-\delta^{18} \mathrm{O}$ NGRIP tuning are shown in Fig. 5 along with the core $\varepsilon_{\mathrm{Nd}}$ and XRF-Ti/Ca records. Note that the deglacial chronology in the Baltic lowlands (i.e., R3, R4 and R5 events,

204 see below) is entirely independent of ice-core age models since it is only based on ${ }^{14} \mathrm{C}$ ages 205 (Fig. 4 and Table 1).

\section{GEOCHEMICAL RESULTS}

\subsection{X-RAY FLUORESCENCE}

The XRF Ti/Ca and Fe/Ca ratios in core MD95-2002 show a good correlation $(r=0.975 ; p<$ 0.01) all along the sedimentary sequence (Figs 4 and 5), indicating that the Fe and Ti elements fluctuate together from a common source. Higher (lower) values of both ratios are observed during stadials (interstadials), when sedimentation rates in core MD95-2002 (Fig. 3) and turbidite flux in the deep Bay of Biscay (Toucanne et al., 2012; Toucanne et al., 2008) reach

216 high (low) levels (Figs 4 and 5). Taken collectively, the data suggest that the $\mathrm{Fe}$ and $\mathrm{Ti}$ 217 elements are related to terrigenous-siliciclastic components and the carbonate content in the 218 core is mainly due to dilution by terrigenous sediment. Thus, the $\mathrm{Ti} / \mathrm{Ca}$ and $\mathrm{Fe} / \mathrm{Ca}$ can be used 219 as a first-order indication of relative changes in the amount of fine terrigenous components 220 supplied to the core site from Channel River discharge. However, this interpretation is not 221 tenable for the millennial-scale minima in $\mathrm{Ti} / \mathrm{Ca}$ and $\mathrm{Fe} / \mathrm{Ca}$ observed at ca. $24 \mathrm{ka}$ (second part 222 of HS2) and ca. $16 \mathrm{ka}$ (second part of HS1) since anaerobic microbial decomposition of organic matter during these $\sim 300$-years intervals led to bicarbonate supersaturation and precipitation of calcite at site MD95-2002 (Auffret et al., 1996; Toucanne, 2008). These 225 layers, also characterised by abundant ice-rafted debris (IRD; Auffret et al., 2002; Grousset et 226 al., 2000), probably correspond to the 'cemented marls' of Hemming et al. (2004) which they 
interpreted as discharge of icebergs from the Hudson Strait Ice Stream of the LIS to the North

228 Atlantic (i.e., so-called Heinrich Events -HE- that are part of the HS).

\subsection{ND ISOTOPES}

\subsubsection{Modern rivers}

233 The Nd isotopic compositions of the European river sediments analysed in this study $(n=33)$

234 range from $\varepsilon_{\mathrm{Nd}}$ values of -23.3 (Kiiminkijoki River) to -6.7 (Thames River) (Fig. 6 and Table

2). To a large extent, the distribution of $\mathrm{Nd}$ isotopic ratios in European river sediments is

236 controlled by the lithological diversity and the age of the source rocks (Goldstein and 237 Jacobsen, 1987; Goldstein et al., 1984; Peucker-Ehrenbrink et al., 2010). Indeed, very 238 unradiogenic values $\left(-23.3<\varepsilon_{\mathrm{Nd}}<-13.8\right)$ characterise rivers draining the Precambrian Baltic 239 Shield (i.e., Scandinavia), which is known as one of the oldest geological formations in 240 Europe (Bogdanova et al., 2008). In contrast, the Nd isotopic signature of the sediment carried 241 by the rivers draining the Baltic (i.e., Narva, Gauja, Daugava, Neman and Vistula rivers), 242 Paris (e.g., Authie, Orne, Seine, Somme rivers) and London (e.g., Colne, Hamble, Thames 243 rivers) sedimentary basins of Phanerozoic age show more radiogenic values $\left(-16.4<\varepsilon_{\mathrm{Nd}}<\right.$ 244 6.7). This is well-expressed for the western part of the British Isles $\left(\varepsilon_{\mathrm{Nd}}=-10.8 \pm 1.0\right)$ when 245 focusing on the weighted mean $\varepsilon_{\mathrm{Nd}}$ signature (considering the river drainage surface) for the 246 different European regions (Table 2). Such a signature is inherited from the recycling of crust material derived from former orogeny events, such as the Caledonian and Variscan orogens

248 for the western European continent and the southern British Isles (Davies et al., 1985; 249 Michard et al., 1985). Similarly, the filling of the Baltic Basin (i.e., eastern part of the North 250 European Plain; Fig. 1) mainly derived from the erosion of the Baltic Shield (Ūsaityte, 2000), 251 thus explaining the unradiogenic character (i.e., in comparison to that of the western British 
Isles) of the $\mathrm{Nd}$ isotopic signature $\left(-16.4<\varepsilon_{\mathrm{Nd}}<-14.3\right)$ of river sediments from Poland and 253 the Baltic States (Table 2).

\subsubsection{LGM glacigenic sediments}

256 The Nd isotopic compositions of the LGM glacigenic sediment $(n=45)$ collected alongside 257 the EIS southern margin (i.e., Ireland, UK, North Sea, Denmark, Germany and Poland; see Table 3 and associated references for details about their stratigraphy) range from $\varepsilon_{\mathrm{Nd}}$ values of -16.8 (Lønstrup Klint Fm, Denmark) to -0.6 (Kilmore Quay, Ireland) (Fig. 6 and Table 3).

260 With the exception of the very unradiogenic Irish sample from Kilmore Quay (most likely due to its proximity to local Ordovician volcanic rocks), the $\mathrm{Nd}$ isotopic data of the LGM glacigenic sediment resemble that observed for modern rivers at the European scale, with a general decrease from West $\left(\varepsilon_{\mathrm{Nd}}=-11.8 \pm 0.7\right.$ in Ireland; Kilmore Quay sample excluded) to 264 East $\left(\varepsilon_{\mathrm{Nd}}=-15.0 \pm 1.1\right.$ in the North European Plain, Table 3). This indicates that the BIIS and the Irish Sea Ice Stream (ISIS) mobilised more radiogenic sediment that the SIS during the LGM. Interestingly, the Nd isotopic compositions of the LGM glacigenic sediment collected in Denmark $\left(-16.8<\varepsilon_{\mathrm{Nd}}<-13.0\right)$ and Germany $\left(-16.5<\varepsilon_{\mathrm{Nd}}<-12.4\right)$ significantly differ from that encountered in modern river sediments in this region $\left(-12.4<\varepsilon_{\mathrm{Nd}}<-8.9\right.$, see Table 2$)$.

269 This leads to an homogeneous, low $\varepsilon_{\mathrm{Nd}}$ signature of glacigenic material along the southern 270 SIS, from Baltic States to Denmark. This probably highlights both the input of Baltic Shield 271 materials in the North European Plain by the southern SIS margins (Kjær et al., 2003), and the 272 westward transport of sediment from Poland and the Baltic States (see the Neodymium 273 isotope signature for modern rivers in Table 2) in continuous, extensive ice-marginal valleys 274 (Ehlers et al., 2011a; Krzyszkowski et al., 1999) (Figs 1 and 6). 
278 The new MD95-2002 $\varepsilon_{\mathrm{Nd}}$ record shows significant fluctuations over the studied interval (Figs 2794 and 5; Supplementary Material for numeric data). While Nd isotope data are stable around $280 \varepsilon_{\mathrm{Nd}}$ value of -11.5 before $32 \mathrm{ka}$ and after $11 \mathrm{ka}$, the $\mathrm{Nd}$ isotope data largely fluctuate over the $28132-11 \mathrm{ka}$ interval with $\varepsilon_{\mathrm{Nd}}$ values ranging from -14.2 to -9.7 . Such variability in the $\mathrm{Nd}$ 282 isotopic compositions at site MD95-2002 is in agreement with that encountered in both the 283 modern river and LGM glacigenic sediments (Figs 4 and 5). In detail, $\varepsilon_{\mathrm{Nd}}$ values decrease 284 during stadial intervals, especially during HS3 ( 31-29 ka, $\varepsilon_{\mathrm{Nd}}$ down to -13.1), HS2 ( 26-23 285 $\mathrm{ka}, \varepsilon_{\mathrm{Nd}}$ down to -12.7 ) and the early part of HS1 (between $18.2 \pm 0.2$ and $16.7 \pm 0.2 \mathrm{ka}, \varepsilon_{\mathrm{Nd}}$ 286 down to -14.2). Significant excursions ( $\varepsilon_{\mathrm{Nd}}$ down to -14.1) also occur at the end of the LGM, 287 between $22.5 \pm 0.2$ to $21.3 \pm 0.2 \mathrm{ka}$ and between $20.3 \pm 0.2$ to $18.7 \pm 0.3 \mathrm{ka}$. We discuss the 288 paleoenvironmental meaning of the evolution of the $\mathrm{Nd}$ isotopic compositions at site MD952892002 below. Note that we specifically focus our interpretation for sediment older than $16.7 \pm$ $290 \quad 0.2 \mathrm{ka}$ (see below). From this time onwards and until the Early Holocene, the sedimentation in 291 the deep Bay of Biscay is strongly affected by the erosion of the shelf deposits (including the 292 lowstand Channel River delta) in response to the significant sea-level rise and the embayment of the English Channel (Bourillet et al., 2003; Toucanne et al., 2012). For this reason, we do 294 not interpret the MD95-2002 $\varepsilon_{\mathrm{Nd}}$ record throughout the last transgression.

\section{DISCUSSION}

298 5.1 Linking Channel River meltwater discharge and EIS fluctuations 
301 The $\varepsilon_{\mathrm{Nd}}$ detrital value (-11.1) determined for core MD95-2002 surficial sediments (dated at ca.

$302 \quad 1.6 \mathrm{ka}$ ) is very similar to those measured in sediment layers from the Mid and Early Holocene

303 (about $\left.\varepsilon_{\mathrm{Nd}}-11.6\right)$ and from the core-top of a nearby sedimentary record $\left(\varepsilon_{\mathrm{Nd}}-10.9\right.$; KECP-11, 304 see Freslon et al., 2014). Taken together, these data indicate that a $\varepsilon_{\mathrm{Nd}}$ value of about $-11.2 \pm$ $3050.4(1 \mathrm{SD})$ at site MD95-2002 is representative for the present interglacial, and can be used as 306 an estimate for the $\mathrm{Nd}$ isotopic signature of river-borne particles delivered to the coring site 307 by rivers from the NW European margin during highstand conditions. This latter assumption 308 is supported by our compilation of the $\mathrm{Nd}$ isotopic compositions of modern rivers (Table 2). 309 By considering the Channel River as the main sediment source for the Bay of Biscay during 310 glacial lowstands (Toucanne et al., 2010), we thus assume that sediment deposited at site 311 MD95-2002 during the last glacial and characterised by ('interglacial') $\varepsilon_{\mathrm{Nd}}$ values around -11.2 $312 \pm 0.4$ likely indicate a minor contribution of sedimentation from the EIS. Such 'interglacial' $313 \varepsilon_{\mathrm{Nd}}$ value characterises the sediment deposited at site MD95-2002 before ca. $32 \mathrm{ka}$. On the 314 contrary, the MD95-2002 $\varepsilon_{\mathrm{Nd}}$ record shows significant millennial-scale excursions towards 315 both more negative and positive $\varepsilon_{\mathrm{Nd}}$ values, ranging from -14.2 to -9.7 from $32 \mathrm{ka}$ onwards 316 (until about $11 \mathrm{ka}$ ). The observed $\varepsilon_{\mathrm{Nd}}$ changes resemble the high-resolution XRF Ti/Ca and $317 \mathrm{Fe} / \mathrm{Ca}$ records, suggesting that variations in terrigenous inputs are related to changes in the 318 sediment provenance. Changes in both the $\varepsilon_{\mathrm{Nd}}$ and the $\mathrm{XRF} \mathrm{Ti} / \mathrm{Ca}$ and $\mathrm{Fe} / \mathrm{Ca}$ ratios at site 319 MD95-2002 occur concomitantly with changes in the elemental composition ( $\mathrm{Ti} / \mathrm{Ca}$ and $320 \mathrm{Fe} / \mathrm{Ca}$ ratios; Figs 4 and 5) in turbidite-rich sequences from the deep Bay of Biscay (i.e., cores 321 MD03-2690 and MD03-2695; Fig. 1) and increases in the turbiditic frequency at these sites 322 (Toucanne et al., 2012; Toucanne et al., 2008; Fig. 4), implying that they represent peak 323 discharges of the Channel River. Overall, these observations suggest that large changes 324 related to ice-marginal fluctuations of the EIS occurred in the Channel River drainage basin at 
the end of the last glacial and led to corresponding intensification of Channel River runoff and

326 sediment discharge.

\subsubsection{SIS contribution}

Recent work has shown that once the EIS had invaded the lowlands (with the attendant

330 increase of the Channel River drainage area), the sediment flux to the Bay of Biscay was

331 driven by meltwater runoff during ice-sheet retreat rather than by ice-sheet volume in the 332 drainage area (Toucanne et al., 2010). This explains why maximum Channel River discharge 333 did not coincide with the LGM (i.e., the EIS failing to release substantial meltwater volumes; 334 Boulton and Hagdorn, 2006; Boulton et al., 2001; Hubbard et al., 2009) but instead with the 335 deglaciation. Sediment budget (Toucanne et al., 2010) and high-resolution multiproxy marine 336 records (Eynaud et al., 2012; Eynaud et al., 2007; Ménot et al., 2006; Zaragosi et al., 2001) have also demonstrated that the impact of the SIS (and specifically its meltwater) on the

338 Channel River activity abruptly decreased at ca. $17 \mathrm{ka}$. This abrupt diminution of the 339 meltwater runoff is clearly depicted at site MD95-2002 through the strong decrease of both 340 the branched and isoprenoid tetraether (BIT) index (Ménot et al., 2006), a proxy for the 341 relative fluvial input of terrestrial organic matter in the marine environment (Hopmans et al., 342 2004), and the flux of freshwater alga Pediastrum (Zaragosi et al., 2001) (Fig. 5). Considering 343 the new chronostratigraphic framework of core MD95-2002, the timing of this event can be 344 refined to $16.7 \pm 0.2 \mathrm{ka}$. The $\mathrm{XRF} \mathrm{Ti} / \mathrm{Ca}$ and $\mathrm{Fe} / \mathrm{Ca}$ ratios strongly decrease at that time (i.e., 345 to about 0.073 and 0.75 , respectively), which indicate significant decrease in the delivery of 346 terrigenous components from the Channel River at the studied site. Those values, taken 347 together with evidence for the abrupt shutdown of SIS meltwater at $16.7 \pm 0.2 \mathrm{ka}$, could help 348 us to determine the precise timing for peak Channel River discharges related to SIS retreat 349 events throughout the studied period. Indeed, the close evolution of the XRF and $\varepsilon_{\mathrm{Nd}}$ records 
in core MD95-2002 strongly suggest that variations in terrigenous inputs are related to

351 changes in the sediment provenance. As a result, one can assume that values higher than ca. 3520.073 for $\mathrm{Ti} / \mathrm{Ca}$ and ca. 0.75 for $\mathrm{Fe} / \mathrm{Ca}$ in core MD95-2002, highlighted as runoff event $\mathrm{R} 1$ to 353 R5 in Fig. 4, likely indicate SIS meltwater discharge. The enhanced Channel River runoff 354 during the R1 to R5 events is supported both by the parallel increase of the BIT-index (Ménot 355 et al., 2006) and the flux of freshwater alga Pediastrum at site MD95-2002 (Zaragosi et al., 356 2001) and the increase of the turbidite frequency in the deep Bay of Biscay (Fig. 5). Our 357 determination of the runoff events, based on XRF ratios detailed in Fig. 4, is strongly 358 supported by the isotopic dataset. Maxima in the XRF records (i.e., Ti/Ca $>0.073$ and $\mathrm{Fe} / \mathrm{Ca}$ $359>0.75$; R1 to R5 events in Fig. 4) correspond to minima in the Nd isotopic compositions 360 [mean $\varepsilon_{\mathrm{Nd}}$ value of $-12.7 \pm 0.9(n=53)$, with $\varepsilon_{\mathrm{Nd}}$ values down to -14.2; Figs 4 and 5]. Only a 361 slight lag (0.5 kyr maximum) between the $\mathrm{Nd}$ isotopic compositions and the XRF records is 362 seen for the R4 event $(20.3 \pm 0.2$ to $18.7 \pm 0.3 \mathrm{ka})$, thus questioning the temporal limits of this 363 event. Nevertheless, for this time interval, the uncertainty of these limits (0.5 kyr maximum) 364 is in the range of that (up to $0.4 \mathrm{kyr}$ ) of the MD95-2002 chronology (Fig. 3). Moreover, the 365 R1 to R5 events defined by the XRF ratios include $>85 \%$ of the MD95-2002 sediment 366 samples (older than $16.7 \pm 0.2 \mathrm{ka}$; see above) with an $\varepsilon_{\mathrm{Nd}}$ signature of possible SIS source. 367 The Nd isotopic compositions of potential source regions (Fig. 6; Tables 2 and 3) show that 368 the river-borne particles delivered to the coring site during the R1 to R5 events were derived 369 mainly from east of the Dover Strait, precisely from the North Sea region $[-12.2 \pm 1.5$ (and $37013.1 \pm 0.8$ for East UK) for LGM glacigenic sediments] and the North European Plain [-13.4 $371 \pm 1.9$ for modern rivers, and from $-14.8 \pm 1.3$ (western part) to $-15.1 \pm 0.8$ (eastern part) for 372 LGM glacigenic sediments].

373 Both the BIIS (e.g., Clark et al., 2012a) and the SIS (e.g., Sejrup et al., 2000; Sejrup et al., 374 2009) invaded the North Sea basin during the Pleistocene leading to southwards routing of the 
375 North Sea fluvial systems through the Dover Strait (Busschers et al., 2007; Gibbard, 1988;

376 Gupta et al., 2007; Toucanne et al., 2009a; Toucanne et al., 2009b; Toucanne et al., 2010). As

377 a consequence, the North Sea basin then connects the Channel River to the North European

378 Plain and the extensive southern margin of the SIS (Toucanne et al., 2010). Recent results

379 show that the North Sea was covered by ice during the last glacial period, from ca. 30 to 18 -

38016 ka (Bradwell et al., 2008; Carr et al., 2006; Clark et al., 2012a; Graham et al., 2010). On 381 this basis, we conclude that peak Channel River discharges R1 to R5 identified from $30.7 \pm$ 0.7 to $28.9 \pm 0.4 \mathrm{ka}(\mathrm{R} 1)$, from $24.3 \pm 0.3$ to $23.4 \pm 0.3 \mathrm{ka}(\mathrm{R} 2$; see below for details concerning these temporal limits), from $22.5 \pm 0.2$ to $21.3 \pm 0.2 \mathrm{ka}$ (R3), from $20.3 \pm 0.2$ to $18.7 \pm 0.3 \mathrm{ka}(\mathrm{R} 4)$ and from $18.2 \pm 0.2$ to $16.7 \pm 0.2 \mathrm{ka}(\mathrm{R} 5)$ are related to SIS retreat events 385 (Figs 4 and 5; Table 4).

Interestingly, minima in the $\mathrm{Nd}$ isotopic compositions of the $\mathrm{R} 2$ to $\mathrm{R} 5$ events gradually increases (i.e., $\varepsilon_{\mathrm{Nd}}$ down to $-12,7,-13.4,-14,1$ and $-14,2$ during the R2, R3, R4 and R5 events, respectively). This could indicate that the SIS contribution in peak Channel River discharges increased through time. By considering the unradiogenic character of the drainage basins of the eastern North European Plain in comparison to those of the western North European Plain (Table 2), this could also highlight (for a strict SIS source) the increasing contribution of the southeastern sector of the ice-sheet. In such a case, a significant contribution of the southeastern sector of the SIS is expected for the R3, R4 and R5 event while a southwestern

394 contribution is likely for R2. These hypothesis are confronted with paleogeographical 395 reconstructions in the following discussion (see discussion, part 5.2).

\subsubsection{BIIS contribution}

398 The high $\varepsilon_{\mathrm{Nd}}$ values (up to -9.6) found between about $28.5 \mathrm{ka}$ and $24 \mathrm{ka}$ indicate the contribution from of a source distinct from both the 'interglacial' riverine background and the 
SIS. By considering both the geographical distribution for European ice-sheets during the last 401 glacial (Ehlers et al., 2011) and the Nd isotopic compositions of potential source regions (Figs 5 and 6; Tables 2 and 3), we propose that the river-borne particles delivered to site MD952002 during this interval were derived mainly from the western British Isles and the western BIIS (Figs 4 and 5). Recent compilations suggest that western sectors of the BIIS first reached their local last glacial maxima ca. 28-25 kyr ago (Clark et al., 2012a; Clark et al., 2012b; Clark et al., 2009; McCabe et al., 2007; Scourse et al., 2009). Chiverrell et al. (2013), using a Bayesian statistical integration of chronological data, also show a simultaneous southwards advance of the ISIS in Channel River basin. The latter caused deposition of the Irish Sea Till (O'Cofaigh and Evans, 2007; O'Cofaigh and Evans, 2001), which shows $\varepsilon_{\mathrm{Nd}}$ signature varying from -11.6 to -0.6 along south coast of Ireland (Table 3 ). This ice-advance was followed by a rapid retreat northwards during HS2 (Scourse et al., 2000), after ca 25.3-24.5 ka, which lead to ice-free conditions in the present-day Celtic Sea no later than ca 23.7-22.9 ka (Chiverrell et al., 2013). Our data supports these reconstructions since the fluctuations of both the MD95$2002 \varepsilon_{\mathrm{Nd}}$ record and the turbidite flux in the northern Bay of Biscay probably reflect extensive ice cover over Ireland just before HS2 then meltwater reworking of the Irish Sea Till in the course of the ISIS retreat. Interestingly, the collapse of the ISIS (i.e., ca. 24.5-23.7 ka)

417 modelled by Chiverrell et al. (2013) appears to occur simultaneously with a prominent 418 reversal of the $\mathrm{Nd}$ isotopic compositions ( $\varepsilon_{\mathrm{Nd}}$ up to -10) at site MD95-2002. Since this event is 419 stratigraphically embedded within the R2 interval $(24.3 \pm 0.3$ to $23.4 \pm 0.3 \mathrm{ka})$ of SIS origin $420\left(\varepsilon_{\mathrm{Nd}}\right.$ down to -12.7$)$, we define now the $\mathrm{R} 2$ interval as a mixed-source deposit related to a 421 simultaneous retreat of the southern margins of the BIIS and SIS. Thus, the significant gradual decrease in $\varepsilon_{\mathrm{Nd}}$ from -9.9 to -12.7 between $26.3 \pm 0.3 \mathrm{ka}$ and $24.3 \pm 0.3 \mathrm{ka}$ likely 423 highlights a mixing of BIIS- and SIS-sourced sediment, with the progressive dominance of 424 the latter. This period was characterized by increased turbidite frequency (Toucanne et al., 
2012; Toucanne et al., 2008) and higher flux of freshwater alga Pediastrum (Zaragosi et al., 2001) and terrestrial-derived organic matter (i.e., increased BIT-index; Ménot et al., 2006) at site MD95-2002 (Fig. 5). This suggests that the simultaneous ice retreat in Ireland and the North European Plain began earlier than $24.3 \pm 0.3$ (i.e., lower boundary of the R2 event). As a result, we consider that the abrupt increase of the turbiditic activity dated at $25.7 \pm 0.3 \mathrm{ka}$ corresponds to the onset of this regional ice-sheet retreat. Based on these conclusions, we propose that the timing for the $\mathrm{R} 2$ event is now defined from $25.7 \pm 0.3 \mathrm{ka}$ to $23.4 \pm 0.3 \mathrm{ka}$ (Fig. 5 and Table 4).

\subsection{Revisiting the pattern and timing of retreat of the EIS, with a specific focus on the SIS}

Most NH ice sheets had advanced to near their LGM extents by ca. $26 \mathrm{kyr}$ ago according to Clark et al. (2009). Using an extensive compilation of geochronological constraints, the same authors show that the LGM in the western British Isles and the Baltic lowlands was reached from ca. 28.3-28.1 ka and ca. 27.3-25.3 ka, respectively. We have shown previously, in agreement with the modelled chronological data of Chiverrell et al. (2013), that a significant retreat from this maximum position occurred along the southern margin of the western British Isles during the R2 event, from $25.7 \pm 0.3 \mathrm{ka}$ to $23.4 \pm 0.3 \mathrm{ka}$. Paleogeographical reconstructions demonstrate that this sector of the BIIS continuously retreated from this period onward (Chiverrell et al., 2013; Clark et al., 2012a; Clark et al., 2012b). As a result, we assume that the timing of the retreat of the ISIS from $25.7 \pm 0.3 \mathrm{ka}$, that corresponds chronologically with the HS2 (Scourse et al., 2000), provides a new independent constraint for the timing of the early deglaciation of the south-western BIIS.

Contrary to the BIIS (e.g., Clark et al., 2012a), no comprehensive reconstruction for SIS advance and retreat exist to date. As a result, the precise timing for SIS fluctuations during the 
last termination is still debated (e.g., Böse et al., 2012; Houmark-Nielsen et al., 2006; see Fig.

4517 for a thorough review). We have shown previously that the R2 event also probably 452 corresponds to an ice-marginal retreat of the SIS, and of its southwestern sector in particular. 453 The R2 event probably correlates with the ice-margin retreat limited to the North Sea (Sejrup 454 et al., 2009) and the southwest Scandinavia (Ribjerg Fm; Houmark-Nielsen and Kjær, 2003; 455 Larsen et al., 2009) between ca. 27-23 ka. By considering the timing of the onset of the LGM 456 extent in the Baltic lowlands ca. 27.3-25.3 kyr ago (Clark et al., 2009), we assume that this 457 ice-margin retreat, dated here at ca. $25.7 \pm 0.3 \mathrm{ka}$ (and until $23.4 \pm 0.3 \mathrm{ka}$ ), likely provides a chronological constraint for the early deglaciation of the SIS. However the ice retreat observed in southwest Scandinavia between ca. 27-23 ka is known to precede the maximum

460 SIS advance in Denmark (Main Advance, ca. 23-21 ka; Houmark-Nielsen and Kjær, 2003; 461 Larsen et al., 2009) that is coeval with the local last glacial maxima in Germany and Poland 462 (Brandenburg-Leszno Phase, ca. 25-20 ka; Böse et al., 2012) according to Houmark-Nielsen and Kjaer (2003). As a result, the R2 event (and possibly the R1 event as well) is considered to represent a halt (from ca. $25.7 \pm 0.3$ to $23.4 \pm 0.3 \mathrm{ka}$ ) in the final advance of the SIS to its 465 LGM position (i.e., the Brandenburg-Leszno ice-marginal position -IMP- in Germany and 466 Poland, which corresponds to the Main Stationary Line in Denmark; Houmark-Nielsen, 2010; 467 Houmark-Nielsen and Kjær, 2003). This ice-marginal retreat is probably limited to the 468 southwestern sector of the SIS according to field observation (Houmark-Nielsen and Kjær, 469 2003; Larsen et al., 2009; Sejrup et al., 2009) and the $\varepsilon_{\mathrm{Nd}}$ signature $(-12.7)$ of the 470 corresponding peak in Channel River discharge.

471 The $\mathrm{Nd}$ isotope compositions of the $\mathrm{R} 3$ event $\left(\varepsilon_{\mathrm{Nd}}\right.$ down to -13.4$)$ likely indicate that the 472 subsequent ice-marginal retreat of the SIS (i.e., from $22.5 \pm 0.2$ to $21.3 \pm 0.2 \mathrm{ka}$ ) propagates 473 eastwards. Interestingly, the R3 event coincides within age uncertainties with the retreat from 474 LGM moraines in Belarus and Lithuania dated at $22.1 \pm 1.9 \mathrm{ka}$ by Carlson and Winsor (2012) 
475 through the new calibration of ${ }^{10} \mathrm{Be}$ ages of Rinterknecht et al. (2006). Taken together with 476 the maximum ice advance over Denmark, Germany and Poland dated after ca. $23.4 \pm 0.3 \mathrm{ka}$ 477 (i.e., upper limit of the R2 event), the R3 event allows establishment of the precise timing for 478 the onset of the SIS retreat at the end of the LGM at 22.5 $\pm 0.2 \mathrm{ka}$ (Figs 4 and 5, and Table 4). 479 This gives an upper-limit age for the LGM moraines in the Baltic lowlands and indicates by 480 extension that the succession of the R3, R4 and R5 events, all interpreted as ice-marginal 481 retreat in the Baltic lowlands, provides an unique opportunity for reconstruction of the decay 482 of the SIS during the course of the last deglaciation. The succession of meltwater events R3 to 483 R5 reveals that the latter was discontinuous in character. This result is strongly supported by 484 the latest glacial morphostratigraphy in the Baltic lowlands that shows a succession of three 485 moraine belts (namely Brandenburg-Leszno, Frankfurt-Poznan, and Pomeranian in Germany 486 and Poland; Figs 1 and 6), successively younger from south (i.e., LGM) to north, indicating 487 that the SIS margin paused twice during its overall deglacial retreat (see Ehlers et al., 2011a 488 for a thorough review).

489 The initial retreat of the SIS margin at the end of the LGM (i.e., $22.5 \pm 0.2 \mathrm{ka}$ ) was probably 490 limited in extension. Indeed, the peak Channel River discharge at that time (i.e., R3 event) is 491 relatively weak as suggested by the limited input of sediment and organic material in the Bay 492 of Biscay (Fig. 5). On the contrary, the SIS receded substantially during the subsequent R4 493 (ca. $20.3 \pm 0.2$ to $18.7 \pm 0.3 \mathrm{ka}$ ) and R5 events (ca. $18.2 \pm 0.2$ to $16.7 \pm 0.2 \mathrm{ka}$ ), releasing large 494 amounts of meltwater via ice-marginal valleys from the Baltic lowlands to the North Atlantic. 495 At site MD95-2002, these meltwater fluxes are reflected by the shift towards lower $\varepsilon_{\mathrm{Nd}}$ values 496 (down to -14.2), the deposit of thick laminated facies (Toucanne et al., 2009a; Zaragosi et al., 497 2001), as well as by the marked increase in the freshwater alga Pediastrum (Zaragosi et al., 498 2001) and in the amount of terrestrially-derived organic matter (i.e., increased BIT-index; 499 Ménot et al., 2006). The few excursions towards more positive $\varepsilon_{\mathrm{Nd}}$ values during the R5 event 
indicate that BIIS (or even the Alpine Ice Sheet through the Rhine River; e.g., Busschers et

501 al., 2007) may also have participated in this meltwater pulse.

502 These events, taken together with the millennial-scale intervals of Channel River shutdown

503 between $21.3 \pm 0.2$ and $20.3 \pm 0.2 \mathrm{ka}$, and between $18.7 \pm 0.3$ and $18.2 \pm 0.2 \mathrm{ka}$, probably

504 mirrored the fluctuating retreat and re-advance of the SIS from which the moraine belts

505 originated (Fig. 5 and Table 4). Based on our dataset, we propose that the southern SIS

506 definitely retreated from the Brandenburg-Leszno IMP no later than ca. $20.3 \pm 0.2$ ka (i.e., R4

507 event). The end moraines of the Frankfurt-Poznan Phase, usually considered to represent

508 landforms created by an oscillation during the ice retreat from the maximum Brandenburg-

509 Leszno IMP (Ehlers et al., 2011b), could thus correlate with the short pause in the

510 deglaciation observed from ca. $18.7 \pm 0.3 \mathrm{ka}$ (i.e., end of the $\mathrm{R} 4$ event) to ca. $18.2 \pm 0.2 \mathrm{ka}$

511 (i.e., onset of the R5 event). This event also probably equates with the East-Jylland re-

512 advance in Denmark (Houmark-Nielsen and Kjær, 2003; Larsen et al., 2009) (Fig. 7). The

513 subsequent SIS retreat occurring from ca. $18.2 \pm 0.2$ to $16.7 \pm 0.2 \mathrm{ka}$ (i.e., the R5 event)

514 probably led to ice-free conditions north of the Polish Baltic coast prior to the subsequent

515 Pomeranian ice-advance (Rinterknecht et al., 2006). The pulse of meltwater probably lasted

516 until the disappearance of the ice tongue established over the modern North Sea region. Since

517 then, it is likely that SIS meltwater was diverted towards the Nordic Seas. This coincides with

518 the observed cessation of Channel River activity (Toucanne et al., 2010). Nevertheless, recent

519 reconstruction of the SIS in the East European Plain reveals that the receding margin paused

520 between $17.2 \pm 0.4$ and $15.7 \pm 0.3 \mathrm{ka}$, during the Pomeranian phase (Soulet et al., 2013), in

521 good agreement with new exposure ages for this moraine $(16.4 \pm 1.2 \mathrm{ka}$ to $15.6 \pm 0.6 \mathrm{ka})$

522 (Rinterknecht et al., 2013; Rinterknecht et al., 2012), allowing for the possibility of the

523 Channel River cessation due to another pause in the retreat of the SIS. 
The correlations between our MD95-2002 record and the moraine belts should be taken with

525 caution with regard to the complexity of the morphostratigraphy in the Baltic lowlands (e.g., see Ehlers et al., $2011 \mathrm{~b}$ for a thorough review in Northern Germany). Nevertheless, our chronology for retreat and re-advance of the SIS throughout the deglaciation reconciles most of the earlier chronological reconstructions proposed all along the southern SIS margin (see Fig. 7 and the associated references). Thus, the millennial-scale timing for discrete input of sediment-laden meltwater of SIS origin in the Bay of Biscay reveals that the whole southern SIS margin fluctuated synchronously (during the R3, R4 and R5 events in particular), likely in response to changes in the mass balance of the Baltic Sea Ice Stream (Boulton et al., 2001). Interestingly, core MD01-2461 located off Ireland shows peaks of BIIS-sourced IRD 534 commencing at $\sim 22.4 \mathrm{ka}, \sim 20.3 \mathrm{ka}$ and $\sim 18.4 \mathrm{ka}$, which lasted between 1.6 to $1.0 \mathrm{kyr}$ (Peck et 535 al., 2006) and correlated with the R3, R4 and R5 events, respectively. This reveals synchronous instability of both the eastern (i.e., SIS) and western (i.e., BIIS) parts of the EIS, thus pointing out that the EIS as a whole was responding to a large-scale climate forcing. This result as well as its consistency with regard to the chronology of the LIS (discussed below) strongly challenges the emerging view for time-transgressive ice-sheet fluctuations in Europe 540 during the deglaciation (Böse et al., 2012). The mixing of various types of material (boulders, quartz, feldspars, wood, plant detritus, bones, shells, etc.) and various methods $\left({ }^{10} \mathrm{Be},{ }^{36} \mathrm{Cl}\right.$, ${ }^{26} \mathrm{Al}$, OSL, IRSL, ${ }^{14} \mathrm{C}$ ) - with their own uncertainties regarding both the age (depending of e.g. cosmogenic radionuclide production rate) and their interpretation (e.g., Heyman et al., 2011;

544 Houmark-Nielsen et al., 2012) - to date the continental glacigenic deposits originated from the 545 rapid ice-marginal fluctuations of the SIS discussed above likely explains most of the 546 chronological discrepancies recently highlighted along the SIS moraine belts (Böse et al., 547 2012). A summary for the timing of SIS fluctuations recognised on land [i.e., Pomeranian, 548 Frankfurt-Poznan, Brandenburg-Leszno (e.g., Ehlers et al., 2011b; Houmark-Nielsen and 
Kjær, 2003) and even Kattegat and Klintholm phases (Houmark-Nielsen, 2010; Möller and

550 Murray, 2015)] is proposed in Figs 5 and 7, and Table 4.

5.3 Comparing the timing of retreat of the SIS and LIS

The pattern of ice-margin retreat for the southern SIS margin, with initial retreat at $22.5 \pm 0.2$

555 ka followed by more extensive retreat after $20.3 \pm 0.2 \mathrm{ka}$, is similar in timing to that of the southern LIS margin (Carlson and Winsor, 2012; Curry and Petras, 2011; Ullman et al., 2015). Recent compilation of ${ }^{10} \mathrm{Be}$ surface exposure ages focusing on southern LIS lobes reveal that the southern LIS began retreating at $23.0 \pm 0.6 \mathrm{ka}$ (Ullman et al., 2015). This initial retreat, concomitant with the R3 event in Europe, was limited during the next $\sim 3 \mathrm{kyr}$, but was 560 then followed by more rapid retreat (e.g., by $19.4 \pm 0.7$ ka for the southern Green Bay Lobe). The detailed comparison of our SIS retreat chronology with those of the well-dated Lake

562 Michigan and Miami-Scloto lobes (Ullman et al., 2015) show that large-scale recessions of 563 the southern LIS coincide within age uncertainties with the R4 and R5 events in Europe (Fig. 564 5). The latter event also coincides with a rapid deglaciation $(50-100 \mathrm{~m} / \mathrm{yr})$ of central 565 Connecticut, southeastern LIS (Ridge et al., 2012). In addition, massive discharges of 566 freshwater in the northeast Pacific also reveal enhanced ablation of the Cordilleran Ice-Sheet 567 during these two intervals (Lopes and Mix, 2009). Thus, both the timing for the early 568 deglaciation (from $23.0 \pm 0.6 \mathrm{ka}$ and from $22.5 \pm 0.2 \mathrm{ka}$ in North America and in Europe, 569 respectively) and the acceleration of the margin retreat on both sides of the North Atlantic 570 (from $20.4 \pm 0.3 \mathrm{ka}$ and from $20.3 \pm 0.2 \mathrm{ka}$ in North America and in Europe, respectively) 571 occurred simultaneously. Recent climate-surface mass balance simulations revealed that the 572 small increase in northern summer insolation ca. 24-23 ka (Fig. 5), and the acceleration in 573 rising insolation thereafter (i.e., ca. $20 \mathrm{ka}$ ), is potentially sufficient to explain the deglacial 
574 pattern of the LIS (Abe-Ouchi et al., 2013; Ullman et al., 2015). The similar timing observed

575 for retreat of the LIS and SIS, by excluding local climate anomaly or dynamic instability as 576 possible forcings, strongly supports this assumption. In addition, the similar timing for

577 enhanced margin retreat on both sides on the North Atlantic supports the contention that the 578 EIS, together with the LIS, was an important source for the 5-10 m eustatic sea-level rise that 579 occurred sometime between 20 and 19 ka (Carlson and Clark, 2012; Clark et al., 2004b; 580 Yokoyama et al., 2000).

581 Finally, our dataset reveals that some significant ice-sheet fluctuations occur simultaneously on both sides of the North Atlantic before the deglaciation, precisely during HS3 and HS2 that correspond to our R1 (ca. $30.7 \pm 0.7$ to $28.9 \pm 0.4 \mathrm{ka}$ ) and R2 (ca. $25.7 \pm 0.3$ to $23.4 \pm 0.3 \mathrm{ka}$ )

584 events, respectively. The latter coincides with discharge of icebergs from the Hudson Strait 585 Ice Stream of the LIS to the North Atlantic (i.e., HE's; Andrews and Tedesco, 1992; 586 Hemming, 2004). These events occurred at the same time that northern summer insolation 587 declined (Fig. 5), thus pointing out a different forcing for these ice-marginal fluctuations. For 588 HS2, Scourse et al. (2000) identifies glacio-eustatic sea-level rise associated with the LIS 589 discharge icebergs through Hudson Strait as a possible feedback mechanism causing 590 destabilisation of marine-terminating ice-streams including the ISIS. However, the $\varepsilon_{\mathrm{Nd}}$ 591 signature of the Channel River meltwater discharges during HS3 and HS2 suggests a 592 significant retreat of the Baltic Ice Stream in the North European lowlands, thus showing that 593 not only marine-terminating ice-streams are involved in these events. Ice lobes from the 594 southwestern LIS (e.g., Puget Lobe of Cordilleran Ice Sheet) began to retreat at about the time 595 of HS (Clark and Bartlein, 1995), producing massive discharges of freshwater in the northeast 596 Pacific (Lopes and Mix, 2009). This supports the synchroneity of ice-sheet fluctuations on 597 both sides of the North Atlantic, and the participation of terrestrial-terminating ice-streams 598 during HS3 and HS2. We discuss the implications of this result below. 
601 We have demonstrated previously that each substantial injection of meltwater to the North Atlantic via the Channel River since the LGM was linked directly to ice recession of the southern EIS margins. Our $\varepsilon_{\mathrm{Nd}}$ proxy record for core MD95-2002 allows one to compare the evolution of the EIS with well-dated paleoclimatic and paleoceanographic records and hence to explore its role in the first steps of the last termination.

The last two EIS retreat (i.e., R4 and R5) events that led to increased meltwater discharges to the North Atlantic occurred at the same time as sharp decreases in sea-surface salinity (Fig. 8e) (Eynaud et al., 2012) and, within age model uncertainties, southward shifts of the polar 609 front in the eastern North Atlantic (Fig. 8c,d) (Bard et al., 2000; Eynaud et al., 2009). Both events correspond to periods of proposed AMOC weakening (Fig. 8f) (Hall et al., 2006;

611 McManus et al., 2004), suggesting that the EIS, in addition to the LIS (Carlson and Winsor, 612 2012; Clark et al., 2007), could have affected the AMOC at the very beginning of the last 613 termination (Roche et al., 2010) with farfield effects as suggested by the concomitant 614 weakening / strengthening of the Chinese / Australasian monsoon, respectively (Fig. 8h) 615 (Ayliffe et al., 2013; Wang et al., 2001). The last major episode of meltwater discharge that 616 freshened sea-surface waters occurred between $18.2 \pm 0.2$ and $16.7 \pm 0.2 \mathrm{ka}$, thus coinciding 617 with the first part of HS1. The persistent EIS melting during the first part of HS1 (as well as 618 during HS2 and HS3), well known as having been a very cold and arid event in the North 619 Atlantic region (Bard et al., 2000), likely involved the role of seasonality (Denton et al., 2005) 620 in a winter-centric mode. Concerning HS1, increasing boreal insolation would have sustained 621 summer warming and attendant ice-margin melting. In turn, early meltwater released to the 622 North Atlantic by decreasing the AMOC rate and northward oceanic heat transfer would have 623 caused hyper-cold winters (Denton et al., 2010). The latter is suggested by the concomitant 
expansion of sea-ice cover in the northern Atlantic region including the Bay of Biscay (Fig. 8b) (Zaragosi et al., 2001). The deposition of a thick, laminated sediment layer at site MD952002 between $18.2 \pm 0.2$ and $16.7 \pm 0.2 \mathrm{ka}$, interpreted as the result of seasonal springsummer meltwater discharges from the Channel River (Toucanne et al., 2009a; Zaragosi et al., 2001), as well as the retreat of the eastern edge of the EIS at the same time (Soulet et al., 2013) supports the winter-dominated seasonality mechanism as a cause for ice sheet deglaciation in 'apparent' cold climate conditions. Such a mechanism also probably explains the rapid retreat of the North American ice sheets observed after $18.4 \pm 0.8 \mathrm{ka}$ (Lopes and Mix, 2009; Ridge et al., 2012; Ullman et al., 2015). Of particular interest, the early HS1 major meltwater event predated LIS iceberg outbursts (HE1) by some 1,500 years (Fig. 8b). In core 634 MD95-2002, this fact is robustly supported because the results of such outbursts are 635 observable in the core stratigraphy. Indeed, the laminated sediment layer recording seasonal 636 Channel River floods during the period of highest activity (i.e., R5 event) is overlain by LIS 637 IRD (after $16.7 \pm 0.2 \mathrm{ka}$ ) (Grousset et al., 2000; Zaragosi et al., 2001). Also, the regional sea638 surface salinity signal in Fig. 8e, derived from the same core, shows that the observed 639 freshening started well before IRD deposition. The recorded major meltwater pulse is coeval 640 both with the AMOC weakening as suggested by both $\mathrm{Pa} / \mathrm{Th}$ measurements on either side of 641 the Atlantic (Hall et al., 2006; McManus et al., 2004) and flow strength reconstruction (Fig. 642 8f) (Praetorius et al., 2008), and with surface and intermediate water warming in the western 643 (sub-) tropical Atlantic (Fig. 8g) (Carlson et al., 2008; Marcott et al., 2011; Rühlemann et al., 644 1999). Based on these considerations, we propose the following scenario. About $18 \mathrm{ka}$, the 645 Channel River system underwent deglacial reactivation in response to the rapid, large-scale 646 recession of the SIS. This, added to the simultaneous rapid melting of the southern LIS 647 (Carlson and Winsor, 2012; Clark et al., 2007; Ullman et al., 2015) and the instability of BIIS 648 ice-streams (Hall et al., 2006; Peck et al., 2006; Scourse et al., 2009), led to a period of 
$649 \sim 1,500$ years of near-continuous meltwater injection into the North Atlantic, resulting in 650 surface water freshening that could have weakened the AMOC and thereby reduced 651 northward oceanic heat transport. As a consequence, the (sub-) tropical Atlantic Ocean 652 probably warmed and, even if reduced, the northern export of warm tropical waters along the 653 NE coast of North America was sufficient to trigger the destabilisation of the LIS marine654 based ice streams (Clark et al., 2007) as suggested by recent modelling studies (Alvarez-Solas 655 et al., 2010; Alvarez-Solas et al., 2013; Marcott et al., 2011). Hence, after $16.7 \pm 0.2$ ka (i.e., 656 end of the R5 event), the massive LIS iceberg surge (HE1; centred at 16-15.5 ka according to 657 Carlson and Clark, 2012) injected large volumes of meltwater into the North Atlantic that 658 sustained AMOC reduction (McManus et al., 2004) and NH stadial conditions until ca. $15 \mathrm{ka}$. 659 The impact of the Channel River meltwater discharges in the initial event of this scenario is 660 potentially possible given that $\mathrm{AMOC}$ is sensitive to freshwater perturbations along the 661 western European margin (Roche et al., 2010) and that the Channel River water discharge at 662 that time (up to $0.4 \mathrm{~Sv}$; Toucanne et al., 2010) was presumably higher than the necessary 663 threshold to affect AMOC [ 0.15 Sv in the Bay of Biscay, see Roche et al. (2010); from 0.05 664 to $0.3 \mathrm{~Sv}$ more generally, see Ganopolski and Rahmstorf (2001), Levine and Bigg (2008), 665 Rahmstorf (1995) among others]. Our findings support results showing that iceberg 666 discharges, or so-called HE's, were the consequence of stadial conditions rather than the cause 667 (Alvarez-Solas et al., 2013; Barker et al., 2015; Bond and Lotti, 1995; Clark et al., 2007).

668 The meltwater-induced weakening of the AMOC leading to the winter-centric HS1 in the 669 North Atlantic region is correlative with a significant bipolar seesaw response (Shakun et al., 670 2012) as shown with the concomitant widespread oceanic/atmospheric warming in the SH 671 (Fig. 8h,i) (Ayliffe et al., 2013; Barker et al., 2009) and large-scale recession of glaciers in 672 Patagonia and New-Zealand (Hall et al., 2013; Putnam et al., 2013). Similarly the first 673 significant NH ice-sheets retreats recorded at $\sim 22 \mathrm{ka}$ and $\sim 20-19$ ka likely triggered a bipolar 
seesaw response in the SH. Indeed, Channel River meltwater discharges during these intervals (i.e., R3 and R4 events) appear to be nearly synchronous with the first deglacial seesaw events marked in the SH by southward shifts of oceanic/atmospheric fronts (Fig. 8h,i) (Ayliffe et al., 2013; Barker et al., 2009; Shakun et al., 2012), glacier recession in Patagonia (Denton et al., 1999; Murray et al., 2012), and warming of Antarctica (Fig. 8j) (WAIS-Divide-Projectmembers, 2013; Weber et al., 2014). At the same time, weakening of the summer monsoon is observed in the NH, especially in East Asia (Duan et al., 2015; Wang et al., 2001). Taken together with the slight AMOC perturbations observed during these intervals (Fig. 8f) (Hall et al., 2006; McManus et al., 2004; Praetorius et al., 2008), our dataset emphasises the high sensitivity of global climate to meltwater releases in the North Atlantic. Similarly, as discussed for HS1 and the delayed discharge of icebergs from the LIS, the retreat of the EIS southern margin and corresponding Channel River meltwater discharges during HS3 and HS2 could have caused the reduction in AMOC responsible for the marine-based ice stream purge cycle (i.e., HE's; Alvarez-Solas et al., 2010; Alvarez-Solas et al., 2013; Barker et al., 2015; Marcott et al., 2011). All the above suggests that the EIS together with the LIS drove climate changes at the end of the last glacial period, and finally participated in creating the necessary environmental changes in both hemispheres that finally pushed the Earth out of the last ice age.

\section{CONCLUSION}

Our Nd isotope record of Channel River meltwater discharges to the North Atlantic provides, after comparison with continental morphostratigraphical evidences and associated glacigenic samples, a continuous and well-dated record for the evolution of the EIS southern margin through the end of the last glacial period and during the deglaciation. Importantly, our results 
show that the pattern of ice-margin retreat for the SIS is similar in timing to that of the

700 southern LIS margin, with moderate ice-sheet retreat (from $22.5 \pm 0.2 \mathrm{ka}$ in the Baltic 701 lowlands) as soon as the northern summer insolation increase (about $23 \mathrm{ka}$ ) and an 702 acceleration of the margin retreat thereafter (from about $20 \mathrm{ka}$ ). By synchronising ice703 marginal fluctuations on land with records of AMOC and climate changes, our data suggest 704 that EIS, together with the LIS, have played a significant role in the first steps of the last 705 termination. EIS recession events in the Baltic lowlands led to substantial injections of 706 meltwater to the North Atlantic via the Channel River between $22.5 \pm 0.2$ and $21.3 \pm 0.2 \mathrm{ka}$, 707 between $20.3 \pm 0.2$ and $18.7 \pm 0.3 \mathrm{ka}$, and between $18.2 \pm 0.2$ and $16.7 \pm 0.2 \mathrm{ka}$ with possible 708 subsequent AMOC destabilisation and interhemispheric climate changes. The last EIS 709 meltwater event starting at ca. $18.2 \pm 0.2 \mathrm{ka}$ was potentially important enough to trigger a 710 pronounced (in amplitude and duration) interhemispheric seesaw event and the so-called HS1 711 in the $\mathrm{NH}$, and persisted for a sufficient duration $(\sim 1500$ years $)$ to allow the subsequent 712 discharge of icebergs from the LIS (HE1) through mid-depth warming in the North Atlantic, 713 thus prolonging HS1 until ca. $15 \mathrm{ka}$. In addition to providing a possible mechanistic 714 explanation for the exceptional duration of HS1, our results provide support for the view that 715 meltwater-induced weakening of the AMOC were inherent to terminations. Finally, our 716 dataset reveals that significant retreat of the EIS southern margin and concomitant increase 717 Channel River meltwater discharges also occurred during HS3 and HS2. We assume, as 718 discussed for HS1 and the delayed LIS iceberg discharge, that such meltwater events, by 719 involving continental parts of $\mathrm{NH}$ ice-sheets, could have functioned as a possible driver of the 720 oceanic perturbations (i.e., AMOC shutdown) responsible for the marine-based ice stream purge cycle, or so-called HE's, that punctuate past glacial periods. 
This work was sponsored by the French National Research Agency (ANR) via the ECOMIST project (\#2010-JCJC-609-01). The authors warmly acknowledge those who kindly

727 supplied the continental sediment samples (P. Antoine, F. Buscheers, S. Carr, S. Clerc, C. 728 Dubrulle-Bruneau, J. Ehlers, A. Elverhoi, D.J.A. Evans, M. Frueggard, P.L. Gibbard, A. 729 Groengroeft, H. Hünecke, G. Kowaleska, D. Krzyszkowski, N.K. Larsen, T. Leipe, C. 730 Lüghtens, J.P. Lunkka, C. Mellett, F. Nordblad, C. O'Cofaigh, J. Patzold, D. Richards, M. 731 Rogerson, I. Smith, A. Trentesaux, G. Vaikutiene, H. Vallius, B. Van Vliet-Lanoë, C. Winter, 732 A. Wheeler, W. Wysota and V. Zelchs), E. Ponzevera for assistance on the Neptune MC733 ICPMS, C. Skonieczny for XRF acquisition, S. Bermell for mapping, S. Barker, G.H. Denton, 734 P.L. Gibbard, V. Rinterknecht and P.U. Clark for discussions, and the reviewers (C. D. Clark and S. Hemming) for their helpful comments, which greatly improved the manuscript. G.S.

736 acknowledges the Postdoctoral Scholar Program at the Woods Hole Oceanographic 737 Institution, with funding provided by the National Ocean Sciences Accelerator Mass 738 Spectrometry Facility. F.E. acknowledges the European Union's Seventh Framework 739 programme "Past4Future". 
FIGURE 1. a, Palaeogeography of western Europe showing the glacial limits of the European

744 Ice Sheet (EIS) including the Scandinavian (SIS) and British-Irish Ice Sheets (BIIS), the Irish 745 Sea Ice Stream (ISIS) (Boulton et al., 2001; Clark et al., 2012a; Ehlers et al., 2011a), and the

746 Channel River hydrographic network (with ice-marginal valleys -urstromtal- in the North 747 European Plain) during the Last Glacial Maximum (LGM) (Bourillet et al., 2003; Gibbard, 748 1988; Toucanne et al., 2010). Filled circles and open squares indicate the location of the 749 modern rivers (Table 2) and LGM glacigenic samples (Table 3), respectively (green: western 750 British Isles and ISIS; blue: Baltic lowlands and southern SIS margin; white: downstream part 751 of Channel River, North Sea and inner SIS), used to constrain the provenance of terrigenous 752 input in core MD95-2002 (yellow star). Br.: Brandenburg-Leszno moraine (deposited 753 between $23.4 \pm 0.3$ and $20.3 \pm 0.2 \mathrm{ka}$ ), Fr.: Frankfurt-Poznan moraine (from $18.7 \pm 0.3$ to 18.2 $754 \pm 0.2 \mathrm{ka}$ ), Pm.: Pomeranian moraine (from $16.7 \pm 0.2$ to $15.7 \pm 0.3 \mathrm{ka}$ ), see the main text and 755 Table 4 for details about this chronology. The white crosses in the Bay of Biscay correspond 756 (from west to east) to the location of cores MD03-2692 (Trevelyan Escarpment), MD03-2690 and MD03-2695 (Armorican turbidite system) (Figs 2 and 4, and Table 1). b, Location of the 758 main marine sediment records discussed in the text and Fig. 8 (red diamonds). Also shown are 759 the extent of the EIS and LIS (white shading) and a simplified pattern of Atlantic Ocean 760 circulation, with the warm saline waters of the North Atlantic current (red arrows) and the 761 return flow pathway of the deep waters (blue arrows). White arrows indicate the main supply 762 sources of freshwater to the North Atlantic. White crosses indicate the location of cores 763 MD03-2690 and MD03-2692 (Figs 2 and 4; Table 1). 
FIGURE 2. Stratigraphic correlation of cores MD03-2692 (left panel) and MD03-2690 (right

766

767

768

769

770

771

772

773

774

775

776

777

778

779

780

781

782

783

784

785

786

787

788

789 panel) with core MD95-2002 (Fig. 1), based on the abundance of the planktic polar foraminifera Neogloboquadrina pachyderma (left coiling; Nps (\%), grey line; Eynaud et al., 2012; Eynaud et al., 2007; Grousset et al., 2000; Mojtahid et al., 2005; Zaragosi et al., 2006; Zaragosi et al., 2001) and the $\mathrm{XRF}-\mathrm{Ti} / \mathrm{Ca}$ ratio (black line; three-points moving average shown as red line; Mojtahid et al., 2005; Zaragosi et al., 2006). Vertical dashed lines represent core-to-core correlations. ${ }^{14} \mathrm{C}$ dated samples (Eynaud et al., 2012; Mojtahid et al., 2005; Toucanne et al., 2008; Zaragosi et al., 2006; Zaragosi et al., 2001) are marked by solid circles on the depth scale, with red and blue circles corresponding to ${ }^{14} \mathrm{C}$ dates transferred to core MD95-2002 from core MD03-2692 and core MD03-2690, respectively. YD: Younger Dryas; BA: Bølling-Allerød; HS: Heinrich Stadial.

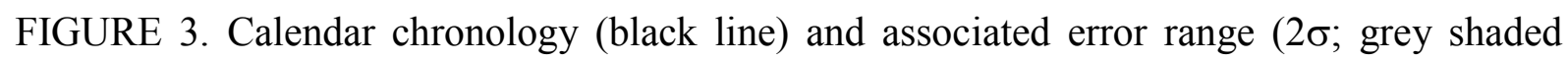
area) for core MD95-2002 based on (i) correlation with the NGRIP ice core isotopes from Greenland (green probability densities, GICC05 chronology; Andersen et al., 2006; Rasmussen et al., 2006), and (ii) calibration of the planktic radiocarbon dates from core MD95-2002 and additional ${ }^{14} \mathrm{C}$ ages from the nearby cores MD03-2690 (Armorican turbidite system) and MD03-2692 (Trevelyan Escarpment) (blue probability distributions; see Figs 1 and 2 for locations and ${ }^{14} \mathrm{C}$ projections, respectively). Information on each age is detailed in Table 1. MD95-2002 chronology was built using the "classical" (non-bayesian) age modeling software Clam (Blaauw, 2010; version 2.2). All radiocarbon age were calibrated after reservoir correction (see the main text for details). ${ }^{14} \mathrm{C}$ age SacA-003247 was removed from final age model because it was clearly an outlier (Table 1). The age-depth model is a smooth spline with the common smoothing parameter 0.3 (Blaauw, 2010) generated through 40.000 iterations. Any model with age-depth reversals was removed. Calculations were performed at 
95\% confidence. The goodness-of-fit is 23.7 (see Blaauw, 2010 for more information on this

791 parameter). Sediment accumulation rates (SAR; cm.kyr ${ }^{-1}$ ) for core MD95-2002 are shown.

792 Note that changes in SAR in core MD95-2002 match the evolution of turbidite frequency in

793 the Armorican turbidite system (Figs 4 and 5) (Toucanne et al., 2012; Toucanne et al., 2008).

794 HS: Heinrich Stadial.

795

796

797

798

799

800

801

802

803

804

805

806

807

808

809

810

811

812

813

814

FIGURE 4.A, a, XRF Ti/Ca (red) and Fe/Ca (blue) ratios for turbidite-rich cores MD03-2690 (until ca. $26 \mathrm{ka}$; continuous lines) and MD03-2695 (only shown for the ca. 22-33 ka interval; dotted lines), Armorican turbidite system (see Fig. 1 for location). Chronology based on correlation with core MD95-2002 (Fig. 2) and supported by ${ }^{14} \mathrm{C}$ ages (see Toucanne et al., 2008 for details). b, Turbidite flux off the Channel River (Toucanne et al., 2012; Toucanne et al., 2010). c, Neodymium isotopic composition in core MD95-2002 (expressed in $\varepsilon_{\mathrm{Nd}}$ ) as a proxy for Channel River sediment provenance. Mean $\varepsilon_{\mathrm{Nd}}$ signatures for LGM glacigenic (squares; Table 3) and modern rivers samples (circles; Table 2) from the western British Isles (BIIS; green) and the North European Plain (SIS; blue) are shown on the right. Considering that $\varepsilon_{\mathrm{Nd}}$ of about $-11.2 \pm 0.4$ provides a mean signature for river-borne particles delivered to the coring site by rivers from the NW European margin during the Holocene, only sediment with $\varepsilon_{\mathrm{Nd}}$ values higher than about -11 are interpreted from BIIS origin. In contrast, sediment with $\varepsilon_{\mathrm{Nd}}$ values lower than about -12 are interpreted from SIS origin. $\mathbf{d}$, XRF Ti/Ca (red) and $\mathrm{Fe} / \mathrm{Ca}$ (blue) ratios for core MD95-2002. The dashed lines highlight the boundaries (i.e., $\mathrm{Ti} / \mathrm{Ca}>0.073$ and $\mathrm{Fe} / \mathrm{Ca}>0.75)$ used to constraint the Channel River runoff events $(\mathrm{R}) 1$ to 5, interpreted as retreat of the southern EIS (see the main text for details). The latter are highlighted by the vertical blue (SIS-origin) / green (BIIS-origin) bars. The arrows at ca. 16 and 24 ka point out the impact of authigenic precipitation of calcite at site MD95-2002 (Auffret et al., 1996; Toucanne, 2008), that probably correspond to the 'cemented marls' of 
815 Hemming et al. (2004) interpreted as 'Hudson Strait' Heinrich events. e, ${ }^{14} \mathrm{C}$ ages with 816 uncertainties, core MD95-2002 (Fig. 3 and Table 1). Note that, for clarity, the age scale 817 between 15 and $23 \mathrm{ka}$ is different from that between 8 and $15 \mathrm{ka}$ and between 23 and $38 \mathrm{ka}$.

818 B, Probability density of the dated levels of the 'deglacial' Channel River runoff event (R) 3 to 8195 (see Fig. 3 for the detailed chronology). Vertical scales are arbitrary. YD: Younger Dryas; 820 BA: Bølling-Allerød; HS: Heinrich Stadial; HE: Heinrich Event.

821

822

FIGURE 5. a, Summer energy (red line, $\tau=400$ ) (Huybers, 2006) and 21 June-20 July 823 insolation for $55^{\circ} \mathrm{N}$ (blue line) (Laskar et al., 2004). b, Greenland temperature (NGRIP ice 824 core) (NGRIP-members, 2004). c, N. pachyderma (left coiling) abundance in core MD958252002 (Zaragosi et al., 2001) tuned to NGRIP ice core record (tuning points -shaded lines826 shown) and ${ }^{14} \mathrm{C}$ dates (see in the lower part of the figure; Table 1). d, Neodymium isotopic 827 composition in core MD95-2002 (expressed in $\varepsilon_{\mathrm{Nd}}$ ) as a proxy for Channel River sediment 828 provenance. Mean $\varepsilon_{\mathrm{Nd}}$ signatures for LGM glacigenic (squares; Table 3) and modern rivers 829 samples (circles; Table 2) from the western British Isles (BIIS; green) and the North European 830 Plain (SIS; blue) are shown on the right. Sediment with $\varepsilon_{\mathrm{Nd}}$ values higher / lower than about $83111 /-12$ are interpreted from BIIS / SIS origin, respectively. e, XRF Ti/Ca (red) and $\mathrm{Fe} / \mathrm{Ca}$ 832 (blue) ratios for core MD95-2002. The arrows indicate the impact of authigenic precipitation 833 of calcite ('cemented marls' of Hemming, 2004, or 'Hudson Strait' Heinrich events) at site 834 MD95-2002. f, Turbidite flux off the Channel River (Toucanne et al., 2012; Toucanne et al., 835 2010). g, Concentration of Pediastrum (green line) (Zaragosi et al., 2001) and branched and 836 isoprenoid tetraether (BIT) index (red line) (Ménot et al., 2006) in MD95-2002. h, EIS (this 837 study; longitude $\sim 10-20^{\circ}$ E) and LIS (Lake Michigan Lobe, LML; Miami-Scloto Lobe, MSL; 838 see Ullman et al., 2015) retreat chronologies; distance north of LGM moraines. Colored 839 circles indicates the timing for the onset of ice-sheet retreat at the end of the LGM. Br.: 
840 Brandenburg-Leszno ice-marginal position -IMP-; Fr.: Frankfurt-Poznan IMP; Pm.: Pomerian

841 IMP. Pre-LGM ice advances of the SIS are also indicated (i.e., Klintholm -Klh.- and Kattegat 842 -Ktt.- ice advances, Denmark; Houmark-Nielsen, 2003; Houmark-Nielsen, 2010; Möller and 843 Murray, 2015). The vertical blue (SIS-origin) / green (BIIS-origin) bars represent the Channel 844 River discharges (i.e., runoff -R- events 1 to 5), interpreted as retreat of the southern EIS. i,

$845{ }^{14} \mathrm{C}$ ages with uncertainties, core MD95-2002 (Fig. 3 and Table 1).

FIGURE 6. a, Palaeogeography of western Europe showing the glacial limits of the European Ice Sheet (EIS), including the Scandinavian (SIS) and British-Irish Ice Sheets (BIIS), the Irish Sea Ice Stream (ISIS) (Boulton et al., 2001; Clark et al., 2012a; Ehlers et al., 2011a), and the

850 Channel River hydrographic network (with ice-marginal valleys in the North European Plain) 851 during the LGM (Bourillet et al., 2003; Gibbard, 1988; Toucanne et al., 2010). Filled circles 852 and open squares indicate the location of the modern river (Table 2) and LGM glacigenic samples (till plains, moraines, ice-marginal valleys, outwash plains and proglacial lakes deposited/formed along the southern margin of the EIS; Table 3), respectively (green: western

855 British Isles and ISIS; purple: eastern British Isles and BIIS; orange: English Channel and 856 downstream part of Channel River; grey: south-central North Sea and confluence of the BIIS 857 and SIS; blue: Baltic lowlands and southern SIS margin; red: Scandinavia and inner SIS) used to constrain the provenance of terrigenous input in core MD95-2002 (yellow star). $\mathrm{Br}$.:

859 Brandenburg-Leszno moraine (deposited between $23.4 \pm 0.3$ and $20.3 \pm 0.2 \mathrm{ka}$ ), Fr.: 860 Frankfurt-Poznan moraine (from $18.7 \pm 0.3$ to $18.2 \pm 0.2 \mathrm{ka}$ ), Pm.: Pomeranian moraine (from $86116.7 \pm 0.2$ to $15.7 \pm 0.3 \mathrm{ka}$; see the main text for details). $\mathbf{b}$, Neodymium isotopic composition 862 (expressed in $\varepsilon_{\mathrm{Nd}}$ ) for modern rivers (filled circles; Table 2) and LGM glacigenic samples 863 (open squares; Table 3) according to their location [i.e., longitude; see Fig. 6a]. Mean $\varepsilon_{\mathrm{Nd}}$ 864 signatures according to the geographic clusters defined in Tables 2 and 3. 
FIGURE 7. Summary of regional ice-sheet chronologies for the southern SIS margin between

86638 and $14 \mathrm{ka}$ (Middle and Late Weichselian). Chronologies, mixing various types of material 867 (boulders, quartz, feldspars, wood, plant detritus, bones, shells, foraminifera, etc.) and various 868 methods were used $\left({ }^{10} \mathrm{Be},{ }^{36} \mathrm{Cl},{ }^{26} \mathrm{Al}\right.$, OSL, IRSL, $\left.{ }^{14} \mathrm{C}\right)$ [Ref. 1: Houmark-Nielsen et al. (2010); 869 2: Houmark-Nielsen and Kjaer (2003); 3: Marks (2012); 4: Houmark-Nielsen (2003); 5: 870 Larsen et al. (2009); 6: Bradwell et al. (2008); 7: Sejrup et al. (1994); 8: Sejrup et al. (2009); 871 9: Clark et al. (2012a); 10: Houmark-Nielsen et al. (2012); 11: Lüghtens and Böse (2011); 12: 872 Heine et al. (2009); 13: Litt et al. (2007); 14: Clark et al. (2009); 15: Marks (2002); 16: 873 Wysota et al. (2009); 17: Rinterknecht et al. (2007); 18: Rinterknecht et al. (2006); 19: Carlson and Winsor (2012); 20: Kjaer et al. (2003); 21: Rinterknecht et al. (2012); 22: Nygard

876

877

878

880

881 882 883 884 et al. (2004); 23: Lüghtens et al. (2011); 24: Rinterknecht et al. (2013); 25: Rinterknecht et al. (2005)]. The LGM sequence is defined by considering the timing of when sectors of the southern SIS (from the North Sea region to the Baltic States) first reached their local last glacial maximum. Pre-LGM and post-LGM sequences are based on sedimentological evidence bracketing the LGM ice advance and retreat sequences. Vertical shaded blue boxes delimit periods (with uncertainties in dark blue) of SIS-derived meltwater input at site MD952002, interpreted as ice-sheet retreat in the Baltic lowlands (runoff -R- events 1 to 5). Based on this interpretation, the chronology for core MD95-2002 was used to revisit the timing for ice margin fluctuations in the Baltic lowlands (Table 4). The latter is summarized in the lower part of the figure (blue symbols) with retreat from the Brandenburg-Leszno Moraine in Germany and Poland (i.e., LGM Sequence) from $20.3 \pm 0.2 \mathrm{ka}$, ice advance to the FrankfurtPoznan ice-marginal position (i.e., Post-LGM Sequence 1) from $18.7 \pm 0.3 \mathrm{ka}$, retreat from the Frankfurt-Poznan Moraine from $18.2 \pm 0.2 \mathrm{ka}$, ice-advance to the Pomeranian Moraine (i.e., Post-LGM Sequence 2) from $16.7 \pm 0.2 \mathrm{ka}$ (this study) and subsequent retreat after 15.7 $\pm 0.3 \mathrm{ka}$ (Soulet et al., 2013). The millennial Nd isotope excursion coupled to high turbidite 
890 flux during HS3 ( 31-29 ka) and HS2 ( 26-23 ka; Figs 3, 4 and 5) affords robust 891 chronological constraints for pre-LGM ice-marginal fluctuations in Europe [e.g., Klintholm 892 and Kattegat ice advances in Denmark (Houmark-Nielsen, 2003; Houmark-Nielsen, 2010; 893 Möller and Murray, 2015); late Middle Vistulian in Poland (Marks, 2012); Rogne Stadial in 894 western Norway (Mangerud et al., 2010)]. Note that the younger episode (i.e., HS3) is 895 synchronous with the boundary between the Middle and the Upper Würmian in the Alps 896 (Spötl et al., 2013), as well as with the timing of the Middle-Upper Pleniglacial transition in 897 central Europe (Kadereit et al., 2013).

898

FIGURE 8. a, Greenland oxygen isotopes (NGRIP ice core; NGRIP-members, 2004). b, Ice900 rafted debris (black line; Zaragosi et al., 2001), BIT-index (red line; Ménot et al., 2006) and 901 concentration of the polar dinocyst specie Islandinium minutum (green line; Auffret et al., 902 2002; Eynaud, 1999; Zaragosi et al., 2001), a proxy for sea-ice cover ( $>6$ months/yr; Rochon 903 et al., 1999), in MD95-2002. c, NE Atlantic sea surface temperature (core SU8118, Fig. 1; 904 Bard et al., 2000). d, N. pachyderma (left coiling) abundance (core MD95-2002; Zaragosi et 905 al., 2001). e, Sea surface salinity (core MD95-2002; Eynaud et al., 2012). f, Proxies for 906 AMOC strength : ${ }^{231} \mathrm{~Pa} /{ }^{230} \mathrm{Th}$ ratio at site OCE326-GGC5 (blue line, Fig. 1; McManus et al., 907 2004) and DAPC2 (grey line, Fig. 1; Hall et al., 2006), and grain-size data (i.e., flow 908 strength, purple line) from ODP Site 984, Southern Iceland (Praetorius et al., 2008). g, 909 Western tropical Atlantic SST (core M35003-4, Fig. 1; Rühlemann et al., 1999). h, Stalagmite 910 oxygen isotopes from Flores, Indonesia (Ayliffe et al., 2013). i, SE Atlantic polar foraminifera 911 species (core TNO57-21, Fig. 1; Barker and Diz, 2014; Barker et al., 2009). j, West 912 Antarctica oxygen isotopes (WAIS Divide ice core) (WAIS-Divide-Project-members, 2013). 913 The vertical blue bars represent the Channel River discharges (i.e., runoff -R- events 3 to 5), 914 interpreted as retreat of the southern SIS. 
917 TABLE 1. Calibration of ${ }^{14} \mathrm{C}$ dates [Ref. 1: Zaragosi et al. (2001); 3: Zaragosi et al. (2006); 4:

918 Toucanne et al. (2008); 5: Eynaud et al. (2007); 6: Grousset et al. (2000); 8: Auffret et al. 919 (2002)] was performed using Clam software (Blaauw, 2010) with the IntCal13 calibration 920 curve (Reimer et al., 2013) (see part 3 for details). NGRIP tie-points (i.e., onset of Greenland

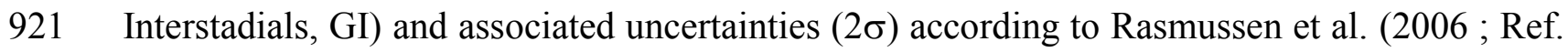
9222 in the table) and Andersen et al. (2006; Ref. 7).

923

924 TABLE 2. Neodymium isotope signature of the clay-silt fraction $(<63 \mu \mathrm{m})$ of some European 925 rivers. Measured ${ }^{143} \mathrm{Nd} /{ }^{144} \mathrm{Nd}$ ratios are reported in $\varepsilon_{\mathrm{Nd}}$ notation, 926 $\left[\left({ }^{143} \mathrm{Nd} /{ }^{144} \mathrm{Nd}\right)_{\text {sample }}\left({ }^{143} \mathrm{Nd} /{ }^{144} \mathrm{Nd}\right)_{\mathrm{CHUR}}-1\right] \times 10^{4}$, using $\left({ }^{143} \mathrm{Nd} /{ }^{144} \mathrm{Nd}\right)_{\mathrm{CHUR}}=0.512638$ 927 (Jacobsen and Wasserburg, 1980). Geographic clusters (with weighted mean $\varepsilon_{\mathrm{Nd}}$ signature 928 considering the river drainage surface) correspond to potential sediment sources at site MD95-2002 according to the palaeogeography of western Europe during the LGM (Fig. 1). Note that very unradiogenic values $\left(-23.3<\varepsilon_{\mathrm{Nd}}<-13.8\right)$ characterise rivers draining the Baltic 931 Shield (i.e., Scandinavia) and the southeastern Baltic rivers (i.e., North European Plain 932 East). ISIS: Irish Sea Ice Stream; BIIS: British-Irish Ice Sheet; SIS: Scandinavian Ice Sheet.

934 TABLE 3. Neodymium isotope signature of the clay-silt fraction $(<63 \mu \mathrm{m})$ of LGM glacigenic 935 sediment samples. Measured ${ }^{143} \mathrm{Nd} /{ }^{144} \mathrm{Nd}$ ratios are reported in $\varepsilon_{\mathrm{Nd}}$ notation, $936\left[\left({ }^{143} \mathrm{Nd} /{ }^{144} \mathrm{Nd}\right)_{\text {sample }}\left(\left(^{143} \mathrm{Nd} /{ }^{144} \mathrm{Nd}\right)_{\text {CHUR }}-1\right] \times 10^{4}\right.$, using $\left({ }^{143} \mathrm{Nd} /{ }^{144} \mathrm{Nd}\right)_{\mathrm{CHUR}}=0.512638$ 937 (Jacobsen and Wasserburg, 1980). Samples were collected from LGM glacial environments 938 along the southern margins of the Irish Sea Ice Stream (ISIS), of the British-Irish (BIIS) and 939 Scandinavian (SIS) ice-sheets and in the course of the Channel River (Fig. 1). Geographic 
940 clusters (with mean $\varepsilon_{\mathrm{Nd}}$ signature) correspond to potential sediment sources at site MD95-

9412002 according to the palaeogeography of western Europe during the LGM (Fig. 1) [Ref. 1:

942 O'Cofaigh and Evans (2007); 2: McCabe et al. (1990) ; 3: Clerc et al. (2012); 4: Lunkka

943 (1988); 5: Evans and Thomson (2010); 6: Mellett et al. (2012); 7: Van Vliet-Lanöe et al.

944 (2010); 8: Carr et al. (2006); 9: Houmark-Nielsen and Kjaer (2003) ;10: Pedersen (2005); 11:

945 Houmark-Nielsen (1987); 12: Kabel (Kabel, 1983); 13: Lüghtens et al. (2010); 14: Lüghtens

946 et al. (2011); 15: Weckwerth (2011); 16: Narloch et al. (2012); 17: Wysota et al. (2009); 18:

947 Tylman et al. (Tylman et al., 2012); 19: Lesemann et al. (2010); 20: Krzyskowski et al.

948 (1999)]. Note that the mean $\varepsilon_{\mathrm{Nd}}$ signature for the ISIS region $(-11.8 \pm 0.7)$ does not include the

949 sample from Kilmore Quay $(-0.6 \pm 0.3)$. IMV: ice-marginal valleys; IMP: ice-marginal

950 position; IA: ice advance; Fm: formation; Dmm: Diamict, matrix-supported, massive; Dms:

951 Diamict, matrix-supported, stratified.

952

953 TABLE 4. Timing for Channel River meltwater discharges (i.e., runoff -R- events 1 to 5) and 954 tentative correlation with the latest glacial morphostratigraphy (i.e., moraine belts, see Fig. 1) 955 in the Baltic lowlands.

956

957 SUPPLEMENTARY TABLE S1. Neodymium isotopic composition for MD95-2002. Note 958 that measured ${ }^{143} \mathrm{Nd} /{ }^{144} \mathrm{Nd}$ ratios are reported in $\varepsilon_{\mathrm{Nd}}$ notation, $959\left[\left({ }^{143} \mathrm{Nd} /{ }^{144} \mathrm{Nd}\right)_{\text {sample }}\left(\left(^{143} \mathrm{Nd} /{ }^{144} \mathrm{Nd}\right)_{\mathrm{CHUR}}-1\right] \times 10^{4}\right.$, using $\left({ }^{143} \mathrm{Nd} /{ }^{144} \mathrm{Nd}\right)_{\mathrm{CHUR}}=0.512638$ 960 (Jacobsen and Wasserburg, 1980). 
964

965

966

967

968

969

970

971

972

973

974

975

976

977

978

979

980

981

982

983

984

985

986

987

988

989

990

991

992

993

994

995

996

997

998

999

1000

1001

1002

1003

1004

1005

1006

1007

1008

1009
Abe-Ouchi, A., Saito, F., Kawamura, K., Raymo, M.E., Okuno, J., Takahashi, k. and Blatter, H., 2013. Insolation-driven 100,000-year glacial cycles and hysteresis of ice-sheet volume. Nature, 500: 190-194.

Alvarez-Solas, J., Charbot, S., Ritz, C., Paillard, D., Ramstein, G. and Dumas, C., 2010. Links between ocean temperature and iceberg discharge during Heinrich events. Nature Geoscience, 3: 122-126.

Alvarez-Solas, J., Robinson, A., Montoya, M. and Ritz, C., 2013. Iceberg discharges of the last glacial period driven by oceanic circulation changes. Proceedings of the National Academy of Sciences, 110(41): 16350-16354.

Andersen, K.K. et al., 2006. The Greenland Ice Core Chronology 2005, 15-42 kyr. Part 1: constructing the time scale. Quaternary Science Reviews, 25(23-24): 3246-3257.

Andrews, J.T. and Tedesco, K., 1992. Detrital carbonate-rich sediments, northwestern Labrador Sea: implications for ice-sheet dynamics and iceberg rafting (Heinrich) events in the North Atlantic. Geology, 20: 1087-1090.

Arz, H.W., Pätzold, J. and Wefer, G., 1998. Correlated millennial-scale changes in surface hydrography and terrigenous sediment yield inferred from Last-Glacial marine deposits off northeastern Brazil. Quaternary Research, 50(2): 157-166.

Auffret, G., Zaragosi, S., Dennielou, B., Cortijo, E., Van Rooij, D., Grousset, F., Pujol, C., Eynaud, F. and Siegert, M., 2002. Terrigenous fluxes at the Celtic margin during the last glacial cycle. Marine Geology, 188(1-2): 79-108.

Auffret, G.A., Boelaert, A., Vergnaud-Grazzini, C., Muller, C. and Kerbrat, R., 1996. Identification of Heinrich Layers in core KS 01 North-Eastern Atlantic $\left(46^{\circ} \mathrm{N}, 17^{\circ} \mathrm{W}\right)$, implications for their origin. Marine Geology, 131(1-2): 5-20.

Ayliffe, L.K. et al., 2013. Rapid interhemispheric climate links via the Australasian monsoon during the last deglaciation. Nature Communications, 4: doi:10.1038/ncomms3908.

Bard, E., Rostek, F., Turon, J.L. and Gendreau, S., 2000. Hydrological impact of Heinrich events in the subtropical Northeast Atlantic. Science, 289: 1321-1324.

Barker, S., Chen, J., Gong, X., Jonkers, L., Knorr, G. and Thornalley, D., 2015. Icebergs not the trigger for North Atlantic cold events. Nature, 520: 333-338.

Barker, S. and Diz, P., 2014. Timing of the descent into the last Ice Age determined by the bipolar seesaw. Paleoceanography, 29, doi:10.1002/2014PA002623.

Barker, S., Diz, P., Vautravers, M.J., Pike, J., Knorr, G., Hall, I.R. and Broecker, W.S., 2009. Interhemispheric Atlantic seesaw response during the last deglaciation. Nature, 457: 1097-1103.

Bayon, G., Barrat, J.-A., Etoubleau, J., Benoit, M., Revillon, S. and Bollinger, C., 2009. Determination of rare earth elements, Sc, Y, Zr, Ba, Hf and Th in geological samples by ICP-MS after Tm addition and alkaline fusion. Geostandards Geoanalytical Research, 33: 51-62.

Bayon, G., Dennielou, B., Etoubleau, J., Ponzevera, E., Toucanne, S. and Bermell, S., 2012. Intensifying Weathering and Land Use in Iron Age Central Africa. Science, 335: 1219-1222.

Bayon, G., German, C.R., Boella, R.M., Mitton, J.A., Taylor, R.N. and Nesbitt, R.W., 2002. An improved method for extracting marine sediment fractions and its application to $\mathrm{Sr}$ and $\mathrm{Nd}$ isotopic analysis. Chemical Geology, 187(3-4): 179-199.

Blaauw, M., 2010. Methods and code for 'classical' age-modelling of radiocarbon sequences. Quaternary Geochronology, 5: 512-518. 
Bogdanova, S.V., Bingen, B., Gorbatschev, R., Kheraskova, T.N., Klozov, V.I., Puchkov, V.N. and Volozh, Y.A., 2008. The East European Craton (Baltica) before and during the assembly of Rodania. Precambrian Research, 160(1-2): 23-45.

Bond, G., Broecker, W., Johnsen, S., McManus, J., Labeyrie, L., Jouzel, J. and Bonani, G., 1993. Correlations between climate records from North Atlantic sediments and Greenland ice. Nature, 365: 143-147.

Bond, G. and Lotti, R., 1995. Iceberg Discharges into the North Atlantic on Millennial Time Scales During the Last Glaciation. Science, 267: 1005-1010.

Böse, M., Lüghtens, C., Lee, J.R. and Rose, J., 2012. Quaternary glaciations of northern Europe. Quaternary Science Reviews, 44: 1-25.

Boulton, G. and Hagdorn, M., 2006. Glaciology of the British Isles Ice Sheet during the last glacial cycle: form, flow, streams and lobes. Quaternary Science Reviews, 25(23-24): 3359-3390.

Boulton, G.S., Dongelmans, P., Punkari, M. and Broadgate, M., 2001. Paleoglaciology of an ice sheet through a glacial cycle: the European ice sheet through the Weichselian. Quaternary Science Reviews, 20: 591-625.

Boulton, G.S., Smith, G.D., Jones, A.S. and Newsome, J., 1985. Glacial geology and glaciology of the last mid-latitude ice sheets. Journal of the Geological Society, London, 142: 447-474.

Bourillet, J.F., Reynaud, J.Y., Baltzer, A. and Zaragosi, S., 2003. The "Fleuve Manche": the submarine sedimentary features from the outer shelf to the deep-sea fans. Journal of Quaternary Science, 18(3-4): 261-282.

Bradwell, T. et al., 2008. The northern sector of the last British Ice Sheet: Maximum extent and demise. Earth-Science Reviews, 88(3-4): 207-226.

Broecker, W.S., 2006. Was the Younger Dryas triggered by a flood? Science, 312: 11461148.

Broecker, W.S., Andree, M., Wolfli, W., Oeschger, H., Bonani, G. and Kennett, J., 1988. The chronology of the last deglaciation: Implications to the cause of the Younger Dryas event. Paleoceanography, 3(1): 1-19.

Brown, P.A. and Kennett, J.P., 1998. Megaflood erosion and meltwater plumbing changes during last North American deglaciation recorded in Gulf of Mexico sediments. Geology, 26: 599-602.

Busschers, F.S. et al., 2007. Late Pleistocene evolution of the Rhine-Meuse system in the southern North-Sea Basin: Imprints of climate change, sea-level oscillation and glacio-isostacy. Quaternary Science Reviews, 26(25-28): 3216-3248.

Carlson, A.E. and Clark, P.U., 2012. Ice sheet sources of sea level rise and freshwater discharge during the last deglaciation. Reviews of Geophysics, 50: RG4007, doi:10.1029/2011RG000371.

Carlson, A.E., Clark, P.U., Haley, B.A., Klinkhammer, G.P., Simmons, K., Brook, E.J. and Meissner, K.J., 2007. Geochemical proxies of North American freshwater routing during the Younger Dryas cold event. Proceedings of the National Academy of Sciences of the United States of America, 104(16): 6556-6561.

Carlson, A.E., Oppo, D.W., Came, R.E., LeGrande, A.N., Keigwin, L.D. and Curry, W.B., 2008. Subtropical Atlantic salinity variability and Atlantic meridional circulation during the last deglaciation. Geology, 36: 991-994.

Carlson, A.E. and Winsor, K., 2012. Northern Hemisphere ice-sheet responses to past climate warming. Nature Geoscience, 5(9): 607-613.

Carr, S.J., Haflidason, H. and Sejrup, H.P., 2000. Micromorphological evidence supporting Late Weichselian glaciation of the northern North Sea. Boreas, 29: 315-328. 
Carr, S.J., Holmes, R., Van der Meer, J.J.M. and Rose, J., 2006. The Last Glacial Maximum in the North Sea Basin: micromorphological evidence of extensive glaciation. Journal of Quaternary Science, 21(2): 131-153.

Cheng, H., Edwards, R.L., Broecker, W.S., Denton, G.H., Kong, X., Wang, Y., Zhang, R. and Wang, X., 2009. Ice Age Terminations. Science, 326: 248-252.

Chiverrell, R.C. et al., 2013. Bayesian modelling the retreat of the Irish Sea Ice Stream. Journal of Quaternary Science, 28(2): 200-209.

Clark, C.D., Gibbard, P. and Rose, J., 2004a. Pleistocene glacial limits in England, Scotland and Wales. In: Ehlers, J., Gibbard, P.L. (Eds.): Quaternary Glaciations: Extent and Chronology, Vol. 1, Europe. Developments in Quaternary Science. Elsevier, Oxford.: 47-82.

Clark, C.D., Hughes, A.L.C., Greenwood, S.L., Jordan, C. and Sejrup, H.S., 2012a. Pattern and timing of retreat of the last British-Irish Ice Sheet. Quaternary Science Reviews, 44: 112-146.

Clark, J., McCabe, A.M., Bowen, D.Q. and Clark, P.U., 2012b. Response of the Irish Ice sheet to abrupt climate change during the last deglaciation. Quaternary Science Reviews, 35: 100-115.

Clark, P.U. and Bartlein, P.J., 1995. Correlation of late Pleistocene glaciation in the western United States with North Atlantic Heinrich events. Geology, 23(6): 483-486.

Clark, P.U., Dyke, A.S., Shakun, J.D., Carlson, A.E., Clark, J., Wohlfarth, B., Mitrovica, J.X., Hostetler, S.W. and McCabe, A.M., 2009. The Last Glacial Maximum. Science, 325: 710-714.

Clark, P.U., Hostetler, S.W., Pisias, N.G., Schmittner, A. and Meissner, K.J., 2007. Mechanisms for an 7-Kyr Climate and Sea-Level Oscillation During Marine Isotope Stage 3, in Ocean Circulation: Mechanisms and Impacts - Past and Future Changes of Meridional Overturning (eds A. Schmittner, J. C. H. Chiang and S. R. Hemming), American Geophysical Union, Washington, D. C. doi: 10.1029/173GM15.

Clark, P.U., Marshall, S.J., Clarke, G.K.C., Hostetler, S.W., Licciardi, J.M. and Teller, J.T., 2001. Freshwater forcing of abrupt climate change during the last glaciation. Science, 293(5528): 283-287.

Clark, P.U., McCabe, A.M., Mix, A.C. and Weaver, A.J., 2004b. Rapid sea level rise at 19,000 years ago and its global implications. Science, 304: 1141-1144, doi: 10.1126/science.1094449.

Clark, P.U. et al., 2012c. Global climate evolution during the last deglaciation. Proceedings of the National Academy of Sciences, 109(19): E1134-E1142.

Clerc, S., Buoncristiani, J.F., Guiraud, M., Desaubliaux, G. and Portier, E., 2012. Depositional model in subglacial cavities, Killiney Bay, Ireland. Interactions between sedimentation, deformation and glacial dynamics. Quaternary Science Reviews, 33: 142-164.

Curry, B. and Petras, J., 2011. Chronological framework for the deglaciation of the Lake Michigan lobe of the Laurentide Ice Sheet from ice-walled lake deposits. Journal of Quaternary Science, 26: 402-410.

Davies, G., Gledhill, A. and Hawkesworth, C., 1985. Upper crustal recycling in southern Britain: evidence from Nd and Sr isotopes. Earth and Planetary Science Letters, 75: 112.

Denton, G.H., Alley, R.B., Comer, G.C. and Broecker, W.S., 2005. The role of seasonality in abrupt climate change. Quaternary Science Reviews, 24(10-11): 1159-1182.

Denton, G.H., Anderson, R.F., Toggweiler, J.R., Edwards, R.L., Schaefer, J.M. and Putnam, A.E., 2010. The Last Glacial Termination. Science, 328: 1652-1656. 
1108 Denton, G.H., Heusser, C.J., Lowell, T.V., Schlüchter, C., Andersen, B.G., Heusser, L.E., Moreno, P.I. and Marchant, D.R., 1999. Geomorphology, Stratigraphy, and Radiocarbon Chronology of Llanquihue Drift in the Area of the Southern Lake District, Seno Reloncaví, and Isla Grande de Chiloé, Chile. Geografiska Annaler. Series A, Physical Geography, 81(2): 167-229.

Duan, F., Wu, J., Wang, Y., Edwards, R.L., Cheng, H., Kong, X. and Zhang, W., 2015. A 3000-yr annually laminated stalagmite record of the Last Glacial Maximum from Hulu Cave, China. Quaternary Research, 83(2): 360-369.

Ehlers, J., Gibbard, P.L. and Hughes, P.D., 2011a. Quaternary Glaciations - Extent and Chronology, 15. Elsevier, Amsterdam, 1126 pp.

Ehlers, J., Grube, A., Stephan, H.-J. and Wansa, S., 2011b. Pleistocene glaciations of North Germany-New results, in Ehlers J., Gibbard P.L., Hughes P.D., eds., Quaternary Glaciations: Extent and Chronology-A Closer Look: Developments in Quaternary Science, v. 15, p. 149-162.

Evans, D.J.A. and Thomson, S.A., 2010. Glacial sediments and landforms of Holderness, eastern England: a glacial depositional model for the North Sea Lobe of the BritishIrish Ice Sheet. Earth Science Reviews, 101: 147-189.

Eynaud, F., 1999. Dinoflagellate cyst countings of sediment core MD95-2002, doi:10.1594/PANGAEA.94355.

Eynaud, F. et al., 2009. Position of the Polar Front along the western Iberian margin during key cold episodes of the last 45 ka. Geochemistry, Geophysics, Geosystems, 10, Q07U05, doi:10.1029/2009GC002398.

Eynaud, F. et al., 2012. New constraints on European glacial freshwater releases to the North Atlantic Ocean. Geophysical Research Letters, 39(15): doi:10.1029/2012GL052100.

Eynaud, F., Zaragosi, S., Scourse, J.D., Mojtahid, M., Bourillet, J.F., Hall, I.R., Penaud, A., Locascio, M. and Reijonen, A., 2007. Deglacial laminated facies on the NW European continental margin: the hydrographic significance of British Ice sheet deglaciation and Fleuve Manche paleoriver discharges. Geochemistry, Geophysics, Geosystems, 8, doi:10.1029/2006GC001496.

Freslon, N. et al., 2014. Rare earth elements and neodymium isotopes in sedimentary organic matter. Geochimica et Cosmochimica Acta, 140: 177-198.

Ganopolski, A. and Rahmstorf, S., 2001. Rapid changes of glacial climate simulated in a coupled climate model. Nature, 409(6817): 153-158.

Gibbard, P.L., 1988. The history of great northwest European rivers during the past three millions years. Phil. Trans. R. Soc. Lond., B318: 559-602.

Goldstein, S.J. and Jacobsen, S.B., 1987. The Nd and Sr isotopic systematics of river-water dissolved material: Implications for the sources of $\mathrm{Nd}$ and $\mathrm{Sr}$ in the seawater. Chemical Geology, 66: 245- 272.

Goldstein, S.J. and Jacobsen, S.B., 1988. Nd and Sr isotopic systematics of river-water suspended material: Implications for crustal evolution. Earth and Planetary Science Letters, 87: 249- 265.

Goldstein, S.L., O'Nions, R.K. and Hamilton, P.J., 1984. A Sm-Nd study of atmospheric dusts and particulate from major river systems. Earth and Planetary Science Letters, 70: 221-236.

Graham, A.G.C., Lonergan, L. and Stoker, M., 2010. Depositional environments and chronology of Late Weichselian glaciation and deglaciation in the central North Sea. Boreas, 39(3): 471-491.

Grousset, F.E., Pujol, C., Labeyrie, L., Auffret, G. and Boelaert, A., 2000. Were the North Atlantic Heinrich events triggered by the behavior of the European ice sheets? Geology, 28(2): 123-126. 
Gupta, S., Collier, J.S., Palmer-Felgate, A. and Potter, G., 2007. Catastrophic flooding origin of shelf valley systems in the English Channel. Nature, 448(7151): 342-345.

Hall, B.L., Porter, C.T., Denton, G.H., Lowell, T.V. and Bromley, G.R.M., 2013. Extensive recession of Cordillera Darwin glaciers in southernmost South America during Heinrich Stadial 1. Quaternary Science Reviews, 62: 49-55.

Hall, I.R., Colmenero-Hidalgo, E., Zahn, R., Peck, V.L. and Hemming, S.R., 2011. Centennial- to millenial-scale ice-ocean interactions in the subpolar northeast atlantic 18-41 kyr ago. Paleoceanography, PA2224, 26.

Hall, I.R., Moran, S.B., Zahn, R., Knutz, P.C., Shen, C.C. and Edwards, R.L., 2006. Accelerated drawdown of meridional overturning in the late-glacial Atlantic triggered by transient pre-H event freshwater perturbation. Geophysical Research Letters, 33(16): L16616, doi:10.1029/2006GL026239.

Heine, K., Reuther, A.U., Thieke, H.U., Schulz, R., Schlaak, N. and Kubik, P.W., 2009. Timing of Weichselian ice marginal positions in Brandenburg (northeastern Germany) using cosmogenic in situ ${ }^{10}$ Be. Zeitschrift für Geomorphologie, 53: 433-454.

Hemming, S.R., 2004. Heinrich events: Massive late Pleistocene detritus layers of the North Atlantic and their global climate imprint. Reviews of Geophysics, 42(1): RG1005 143.

Heyman, J., Stroeven, A.P., Harbor, J.M. and Caffee, M.W., 2011. Too young or too old: Evaluating cosmogenic exposure dating based on an analysis of compiled boulder exposure ages. Earth and Planetary Science Letters, 302: 71-80.

Hopmans, E.C., Weijers, J.W.H., Schefuß, E., Herfort, L., Sinninghe Damsté, J.S. and Schouten, S., 2004. A novel proxy for terrestrial organic matter in sediments based on branched and isoprenoid tetraether lipids. Earth and Planetary Science Letters, 224(12): 107-116.

Houmark-Nielsen, M., 1987. Pleistocene stratigraphy and glacial history of the central part of Denmark. Bulletin of the Geological Society of Denmark, 36: 1-189.

Houmark-Nielsen, M., 2003. Signature and timing of the Kattegat Ice Stream: onset of the Last Glacial Maximum sequence at the southwestern margin of the Scandinavian Ice Sheet. Boreas, 32(1): 227-241.

Houmark-Nielsen, M., 2010. Extent, age and dynamics of Marine Isotope Stage 3 glaciations in the southwestern Baltic Basin. Boreas, 39(2): 343-359.

Houmark-Nielsen, M., Björck, S. and Wohlfarth, B., 2006. 'Cosmogenic ${ }^{10}$ Be ages on the Pomeranian Moraine, Poland': Comments. Boreas, 35.

Houmark-Nielsen, M. and Kjær, K.H., 2003. Southwest Scandinavia, 40-15 kyr BP: palaeogeography and environmental change. Journal of Quaternary Science, 18(8): 769-786.

Houmark-Nielsen, M., Linge, H., Fabel, D., Schnabel, C., Xu, S., Wilcken, K.M. and Binnie, S., 2012. Cosmogenic surface exposure dating the last deglaciation in Denmark: Discrepancies with independant age constraints suggest delayed periglacial landform stabilisation. Quaternary Geochronology, 13: 1-17.

Hubbard, A., Bradwell, T., Golledge, N., Hall, A., Patton, H., Sugden, D., Cooper, R. and Stoker, M., 2009. Dynamic cycles, ice streams and their impact on the extent, chronology and deglaciation of the British-Irish ice sheet. Quaternary Science Reviews, 28(7-8): 758-776.

Huybers, P., 2006. Early Pleistocene glacial cycles and the integrated summer insolation forcing. Science, 313: 508-511.

Jacobsen, S.B. and Wasserburg, G.J., 1980. Sm-Nd isotopic evolution of chondrites. Earth and Planetary Science Letters, 50: 139-155. 
Jennerjahn, T.C., Ittekkot, V., Arz, H.W., Behling, H., Patzold, J. and Wefer, G., 2004. Asynchronous Terrestrial and Marine Signals of Climate Change during Heinrich Events. Science, 306: 2236-2239.

Kabel, C., 1983. The Brodtener Ufer Cliff. In Ehlers, J. (Eds), Glacial deposits in North-West Europe. Rotterdam, Balkema, 325-327.

Kadereit, A., Kind, C.J. and Wagner, G.A., 2013. The chronological position of the Lohne Soil in the Nußloch loess section - re-evaluation for a European loess-marker horizon. Quaternary Science Reviews, 59: 67-86.

Kjær, K.H., Houmark-Nielsen, M. and Richardt, N., 2003. Ice-flow patterns and dispersal of erratics at the southwestern margin of the last Scandinavian Ice Sheet: signature of palaeo-ice streams. Boreas, 32: 130-148.

Knutz, P.C., Zahn, R. and Hall, I.R., 2007. Centennial-scale variability of the British Ice Sheet: Implications for climate forcing and Atlantic meridional overturning circulation during the last deglaciation. Paleoceanography, 22(1): PA1207/doi:10.1029/2006PA001298

Krzyszkowski, D., Gizler, H., Jodlowski, J. and Dobosz, T., 1999. Quaternary geology and geomorphology in the zone of the maximum extent of the Weichselian ice sheet between Slawa slaska and Swieciechowa, western Poland. Quaternary studies in Poland, 16: 47-66.

Larsen, N.K., Knudsen, K.L., Krohn, C.F., Kronborg, C., Murray, A.S. and Nielsen, O.B., 2009. Late Quaternary ice sheet, lake and sea history of southwest Scandinavia - a synthesis. Boreas, 38(4): 732-761.

Laskar, J., Robutel, P., Joutel, F., Gastineau, M., Correia, A.C.M. and Levrard, B., 2004. A long-term numerical solution for the insolation quantities of the Earth. Astronomy and Astrophysics, 428(1): 261-285.

Lehman, S.J., Jones, A.G., Keigwin, L.D., Andersen, E.S., Butenko, G. and Ostmo, S.R., 1991. Initiation of Fennoscandian ice-sheet retreat during the last deglaciation. Nature, 349: 513-516.

Lekens, W.A.H., Sejrup, H.P., Haflidason, H., Knies , J. and Richter, T., 2006. Meltwater and ice rafting in the southern Norwegian Sea between 20 to 40 calendar kyr B.P.: Implications for Fennoscandian Heinrich events. Palaeoceanography, 21: doi:10.1029/2005PA001228.

Lesemann, J.E., Piotrowski, J.A. and Wysota, W., 2010. Glacial curvilineations: New glacial landforms produced by longitudinal vortices in subglacial meltwater flows. Geomorphology, 120(3-4): 153-161.

Levine, R.C. and Bigg, G.R., 2008. Sensitivity of the glacial ocean to Heinrich events from different iceberg sources, as modeled by a coupled atmosphere-iceberg-ocean model. Paleoceanography, 23, doi:10.1029/2008PA001613.

Litt, T., Behre, K.-E., Meyer, K.-D., Stephan, H.-J. and Wansa, S., 2007. Stratigraphishe Begriffe für das Quartär des norddeutschland Vereisungsgebietes. Quaternary Science Journal, 56: 7-65.

Lopes, C. and Mix, A.C., 2009. Pleistocene megafloods in the northeast Pacific. Geology, 37: 79-82.

Lüghtens, C. and Böse, M., 2011. Chronology of Weichselian main ice marginal positions in north-eastern Germany. Quaternary Science Journal, 60(2-3): 236-247.

Lüghtens, C., Böse, M. and Preusser, F., 2011. Age of the Pomeranian ice-marginal position in northeastern Germany determined by Optically Stimulated Luminescence (OSL) dating of glaciofluvial sediments. Boreas, 40(4): 598-615. 
Lüghtens, C., Krbetschek, M., Böse, M. and Fuchs, M.C., 2010. Optically stimulated luminescence dating of fluvioglacial (sandur) sediments from north-eastern Germany. Quaternary Geochronology, 5: 237-243.

Lunkka, J.P., 1988. Sedimentation and deformation of the North Sea Droft formation in the Happisburg area, North Norfolk. . In Groot, David G. (ed.) Glaciotectonics Forms and Processes. Balkema, Rotterdam, pp.109-122.

Mangerud, J., Gulliksen, S. and Larsen, E., 2010. ${ }^{14} \mathrm{C}$-dated fluctuations of the western flank of the Scandinavian Ice Sheet 45-25 kyr BP compared with Bølling-Younger Dryas fluctuations and Dansgaard-Oeschger events in Greenland. Boreas, 39(2): 328-342.

Marcott, S.A. et al., 2011. Ice-shelf collapse from subsurface warming as a trigger for Heinrich events. Proceedings of the National Academy of Sciences, 108(33): 1341513419.

Marks, L., 2002. Last Glacial Maximum in Poland. Quaternary Science Reviews, 21(1-3): 103-110.

Marks, L., 2012. Timing of Late Vistulian (Weichselian) glacial phases in Poland. Quaternary Science Reviews, 44: 81-88.

McCabe, A.M. and Clark, P.U., 1998. Ice-sheet variability around the North Atlantic Ocean during the last deglaciation. Nature, 392: 373-376.

McCabe, A.M., Clark, P.U. and Clark, J., 2007. Radiocarbon constraints on the history of the western Irish ice sheet prior to the Last Glacial Maximum. Geology, 35(2): 147-150.

McCabe, A.M., Eyles, N., Haynes, J.R. and Bowen, D.Q., 1990. Biofacies and sediments in an emergent Late Pleistocene glaciimarine sequence, Skerries, east central Ireland. Marine Geology, 94: 23-26.

McManus, J.F., Francois, R., Gherardi, J.M., Keigwin, L.D. and Drown-Leger, S., 2004. Collapse and rapid resumption of Atlantic meridional circulation linked to deglacial climate changes. Nature, 428(6985): 834-837.

Mellett, C.L., Mauz, B., Plater, A.J., Hodgson, D.M. and Lang, A., 2012. Optical dating of drowned landscapes: A case study from the English Channel. Quaternary Geochronology, 10: 201-208.

Ménot, G., Bard, E., Rostek, F., Weijers, J.W.H., Hopmans, E.C., Schouten, S. and Sinninghe Damsté, J.S., 2006. Early reactivation of European Rivers during the last deglaciation. Science, 313: 1623-1625.

Michard, A., Gurret, P., Soudant, M. and Albarède, F., 1985. Nd isotopes in French Phanerozoic shales: external vs. internal aspects of crustal evolution. Geochimica et Cosmochimica Acta, 49: 601-610.

Mojtahid, M., Eynaud, F., Zaragosi, S., Scourse, J., Bourillet, J.F. and Garlan, T., 2005. Palaeoclimatology and palaeohydrography of the glacial stages on Celtic and Armorican margins over the last 360000 yrs. Marine Geology, 224(1-4): 57-82.

Möller, P. and Murray, A.S., 2015. Drumlinised glaciofluvial and glaciolacustrine sediments on the Småland peneplain, South Sweden - new information on the growth and decay history of the Fennoscandian Ice Sheets during MIS 3. Quaternary Science Reviews, 122: $1-29$.

Murray, D.S., Carlson, A.E., Singer, B.S., Anslow, F.S., He, F., Caffee, M., Marcott, S.A., Liu, Z. and Otto-Bliesner, B.L., 2012. Northern Hemisphere forcing of the last deglaciation in southern Patagonia. Geology, 40(7): 631-634.

Narloch, W., Piotrowski, J.A., Wysota, W., Larsen, N.K. and Menzies, J., 2012. The signature of strain magnitude in tills associated with the Vistula Ice Stream of the Scandinavian Ice Sheet, central Poland. Quaternary Science Reviews, 57: 105-120.

NGRIP-members, 2004. High resolution climate record of the northern hemisphere reaching into the last interglacial period. Nature, 431: 147-151. 
Nygard, A., Sejrup, H.P., Haflidason, H., Cecchi, M. and Ottesen, D., 2004. Deglaciation history of the southwestern Fennoscandian Ice Sheet between 15 and $13{ }^{14} \mathrm{C}$ ka BP. Boreas, 33: 1-17.

O'Cofaigh, C. and Evans, D.J.A., 2007. Radiocarbon constraints on the age of the maximum advance of the British-Irish Ice Sheet in the Celtic Sea. Quaternary Science Reviews, 26(9-10): 1197-1203.

O'Cofaigh, C. and Evans, D.J.A., 2001. Sedimentary evidence for deforming bed conditions associated with a grounded Irish Sea Glacier, southern Ireland. Journal of Quaternary Science, 16: 435-454.

Paillard, D., 2015. Quaternary glaciations: from observations to theories. Quaternary Science Reviews, 107: 11-24.

Peck, V.L., Hall, I.R., Zahn, R., Elderfield, H., Grousset, F., Hemming, S.R. and Scourse, J.D., 2006. High resolution evidence for linkages between NW European ice sheet instability and Atlantic Meridional Overturning Circulation. Earth and Planetary Science Letters, 243(3-4): 476-488.

Peck, V.L., Hall, I.R., Zahn, R. and Scourse, J.D., 2007. Progressive reduction in NE Atlantic intermediate water ventilation prior to Heinrich events: Response to NW European ice sheet instabilities. Geochemistry, Geophysics, Geosystems, 8, doi: 10.1029:2006GC001321.

Pedersen, S.A.S., 2005. Structural analysis of the Rubjerg Knude Glaciotectonic Complex, Vendsyssel, northern Denmark. Geological Survey of Denmark and Greenland Bulletin, 8: 1-192.

Peucker-Ehrenbrink, B., Miller, M.W., Arsouze, T. and Jeandel, C., 2010. Continental bedrock and riverine fluxes of strontium and neodymium isotopes to the oceans. Geochemistry, Geophysics, Geosystems, 11, Q03016, doi:10.1029/2009GC002869.

Praetorius, S.K., McManus, J.F., Oppo, D.W. and Curry, W.B., 2008. Episodic reductions in bottom-water currents since the last ice age. Nature Geoscience, 1: 449-452.

Putnam, A.E. et al., 2013. Warming and glacier recession in the Rakaia valley, Southern Alps of New Zealand, during Heinrich Stadial 1. Earth and Planetary Science Letters, 382: 98-110.

Rahmstorf, S., 1995. Bifurcations of the Atlantic thermohaline circulation in response to changes in the hydrological cycle. Nature, 378(6554): 145-149.

Rasmussen, S.O. et al., 2006. A new Greenland ice core chronology for the last glacial termination. Journal of Geophysical Research, 111, D06102, doi:10.1029/2005JD006079.

Reimer, P.J. et al., 2013. Intcal13 and Marine13 radiocarbon age calibration curves 0-50,000 years cal BP. Radiocarbon, 55(4): 1869-1887.

Richter, T.O., Van Der Gaast, S., Koster, B., Vaars, A., Gieles, R., De Stigter, H.C., De Haas, H. and Van Weering, T.C.E., 2006. The Avaatech XRF Core Scanner: technical description and applications to NE Atlantic sediments. In: R.G. Rothwell (Editor), New Techniques in Sediment Core Analysis. Geological Society, Special Publications, pp. 39-50.

Ridge, J.C., Balco, G., Bayless, R.L., Beck, C.C., Carter, L.B., Dean, J.L., Voytek, E.B. and Wei, J.H., 2012. The new North American varve chronology: A precise record of southeastern Laurentide Ice Sheet deglaciation and climate, 18.2-12.5 kyr BP, and correlations with Greenland ice core records. American Journal of Science, 312(7): 685-722.

Rinterknecht, V., Börner, A., Bourlès, D. and Braucher, R., 2013. Cosmogenic ${ }^{10}$ Be dating of ice sheet marginal belts in Mecklenburg-Vorpommern, Western Pomerania (northeast Germany). Quaternary Geochronology, 19: 42-51. 
Rinterknecht, V., Braucher, R., Böse, M., Bourlès, D. and Mercier, J.L., 2012. Late Quaternary ice sheet extents in northeastern Germany inferred from surface exposure dating. Quaternary Science Reviews, 44: 89-95.

Rinterknecht, V.R. et al., 2006. The last deglaciation of the southeastern sector of the Scandinavian ice sheet. Science, 311(5766): 1449-1452.

Rinterknecht, V.R., Marks, L., Piotrowski, J.A., Raisbeck, G.M., Yiou, F., Brook, E.J. and Clark, P.U., 2005. Cosmogenic ${ }^{10}$ Be ages on the Pomeranian Moraine, Poland. Boreas, 34: 186-191.

Rinterknecht, V.R., Pavlovskaya, I.E., Clark, P.U., Raisbeck, G.M., Yiou, F. and Brook, E.J., 2007. Timing of the last deglaciation in Belarus. Boreas, 36: 307-313.

Roche, D., Wiersma, A.P. and Renssen, H., 2010. A systematic study of the impact of freshwater pulses with respect to different geographical locations. Climate Dynamics, 34(7): 997-1013.

Rochon, A., de Vernal, A., Turon, J.L., Matthiessen, J. and Head, M.J., 1999. Recent dinoflagellate cysts of the North Atlantic Ocean and adjacent seas in relation to seasurface parameters. AASP Contribution Serie, 35: 1-152.

Rühlemann, C., Mulitza, S., Müller, P.J., Wefer, G. and Zahn, R., 1999. Warming of the tropical Atlantic Ocean and slowdown of thermohaline circulation during the last deglaciation. Nature, 402: 511-514.

Scourse, J.D., Haapaniemi, A.I., Colmenero-Hidalgo, E., Peck, V.L., Hall, I.R., Austin, W.E.N., Knutz, P.C. and Zahn, R., 2009. Growth, dynamics and deglaciation of the last British-Irish ice sheet: the deep-sea ice-rafted detritus record. Quaternary Science Reviews, 28: 3066-3084.

Scourse, J.D., Hall, I.R., McCave, I.N., Young, J.R. and Sugdon, C., 2000. The origin of Heinrich layers: evidence from $\mathrm{H} 2$ for European precursor events. Earth and Planetary Science Letters, 182(2): 187-195.

Sejrup, H.P., Haflidason, H., Aarseth, I., King, E., Forsberg, C.F., Long, D. and Rokoengen, K., 1994. Late Weichselian glaciation history of the northern North Sea. Boreas, 23: 113.

Sejrup, H.P., Larsen, E., Landvik, J., King, E.L., Haflidason, H. and Nesje, A., 2000. Quaternary glaciations in southern Fennoscandia: evidence from southwestern Norway and the northern North Sea region. Quaternary Science Reviews, 19: 667-685.

Sejrup, H.P., Nygård, A., Hall, A.M. and Haflidason, H., 2009. Middle and Late Weichselian (Devensian) glaciation history of south-western Norway, North Sea and eastern UK. Quaternary Science Reviews, 28(3-4): 370-380.

Shakun, J.D., Clark, P.U., He, F., Marcott, S.A., Mix, A.C., Liu, Z., Otto-Bliesner, B., Schmittner, A. and Bard, E., 2012. Global warming preceded by increasing carbon dioxide concentrations during the last deglaciation. Nature, 484: 49-55.

Soulet, G., Ménot, G., Bayon, G., Rostek, F., Ponzevera, E., Toucanne, S., Lericolais, G. and Bard, E., 2013. Abrupt drainage cycles of the Fennoscandian Ice Sheet. Proceedings of the National Academy of Sciences, 110(17): 6682-6687.

Spötl, C., Reimer, P.J., Starnberger, R. and Reimer, R.W., 2013. A new radiocarbon chronology of Baumkirchen, stratotype for the onset of the Upper Würmian in the Alps. Journal of Quaternary Science, 28(6): 552-558.

Stern, J.V. and Lisiecki, L.E., 2013. North Atlantic circulation and reservoir age changes over the past 41,000 years. Geophysical Research Letters, 40: 3693-3697.

Toucanne, S., 2008. Reconstruction des transferts sédimentaires en provenance du système glaciaire de Mer d'Irlande et du paléofleuve Manche au cours des derniers cycles climatiques. Unpublished PhD thesis, University Bordeaux 1, n³699, pp. 340. 
Toucanne, S. et al., 2009a. Timing of massive 'Fleuve Manche' discharges over the last 350 kyr: insights into the European Ice Sheet oscillations and the European drainage network from MIS 10 to 2. Quaternary Science Reviews, 28(13-14): 1238-1256.

Toucanne, S., Zaragosi, S., Bourillet, J.F., Dennielou, B., Jorry, S.J., Jouet, G. and Cremer, M., 2012. External controls on turbidite sedimentation on the glacially-influenced Armorican margin (Bay of Biscay, western European margin). Marine Geology, 303306: 137-153.

Toucanne, S. et al., 2009b. A 1.2 My record of glaciation and fluvial discharges from the West European Atlantic margin. Quaternary Science Reviews, 28: 2974-2981.

Toucanne, S. et al., 2010. The first estimation of Fleuve Manche palaeoriver discharge during the last deglaciation: Evidence for Fennoscandian ice sheet meltwater flow in the English Channel ca 20-18 ka ago. Earth and Planetary Science Letters, 290: 459-473.

Toucanne, S., Zaragosi, S., Bourillet, J.F., Naughton, F., Cremer, M., Eynaud, F. and Dennielou, B., 2008. Activity of the turbidite levees of the Celtic-Armorican margin (Bay of Biscay) during the last 30,000 years: Imprints of the last European deglaciation and Heinrich events. Marine Geology, 247(1-2): 84-103.

Tylman, K., Piotrowski, J.A. and Wysota, W., 2012. The ice/bed interface mosaic: deforming spots intervening with stable areas under the fringe of the Scandinavian Ice Sheet at Samplawa, Poland. Boreas, 42(2): 428-441.

Ullman, D.J., Carlson, A.E., LeGrande, A.N., Anslow, F.S., Moore, A.K., Caffee, M., Syverson, K.M. and Licciardi, J.M., 2015. Southern Laurentide ice-sheet retreat synchronous with rising boreal summer insolation. Geology, 43(1): 23-26.

Ūsaityte, D., 2000. The geology of the southeastern Baltic Sea: a review. Earth Science Reviews, 50: 137-225.

Van Vliet-Lanoë, B., Gosselin, G., Mansy, J.L., Bourdillon, C., Meurisse-Fort, M., Henriet, J.P., Le Roy, P. and Trentesaux, A., 2010. A renewed cenozoic story of the Strait of Dover. Annales de la Société Géologique du Nord, 17(2): 59-80.

WAIS-Divide-Project-members, 2013. Onset of deglacial warming in West Antarctica driven by local orbital forcing. Nature, 500: 440-444.

Wang, Y.J., Cheng, H., Edwards, R.L., An, Z.S., Wu, J.Y., Shen, C.C. and Dorale, J.A., 2001. A high-resolution absolute-dated late Pleistocene monsoon record from Hulu Cave, China. Science, 294(5550): 2345-2348.

Weber, M.E. et al., 2014. Millenial-scale variability in Antarctic ice-sheet discharge during the last deglaciation. Nature, 510: 134-138.

Weckwerth, P., 2011. Evolution of the Torun Basin in the Late Weichselian. Landform Analysis, 14: 57-84.

Wysota, W., Molewski, P. and Sokolowski, R.J., 2009. Record of the Vistula ice lobes in the Late Weichselian glacial sequence in north-central Poland. Quaternary International, 207(1-2): 26-41.

Yokoyama, Y., Lambeck, K., De Deckker, P., Johnston, P. and Fifield, L.K., 2000. Timing of the Last Glacial Maximum from observed sea-level minima. Nature, 406: 713-716.

Zaragosi, S., Bourillet, J.F., Eynaud, F., Toucanne, S., Denhard, B., Van Toer, A. and Lanfumey, V., 2006. The impact of the last European deglaciation on the deep-sea turbidite systems of the Celtic-Armorican margin (Bay of Biscay). Geo-Marine Letters, 26(6): 317-329.

Zaragosi, S., Eynaud, F., Pujol, C., Auffret, G.A., Turon, J.L. and Garlan, T., 2001. Initiation of the European deglaciation as recorded in the northwestern Bay of Biscay slope environments (Meriadzek Terrace and Trevelyan Escarpment): a multi-proxy approach. Earth and Planetary Science Letters, 188(3-4): 493-507. 
1453 Ziegler, M., Simon, M.H., Hall, I.R., Barker, S., Stringer, C. and Zahn, R., 2013. Development of Middle Stone Age innovation linked to rapid climate change. Nature communications, 4, doi:10.1038/ncomms2897. 


\begin{tabular}{|c|c|c|c|c|c|c|c|c|c|c|c|c|}
\hline Core label & $\begin{array}{c}\text { Depth } \\
\text { (cm) }\end{array}$ & $\begin{array}{l}\text { Depth in core } \\
\text { MD95-2002 } \\
\text { (cm) }\end{array}$ & Lab. Number & Species & $\begin{array}{l}{ }^{14} \mathrm{C} \text { age } \\
\text { (yr BP) }\end{array}$ & $\begin{array}{c}\text { error } \\
(1 \sigma)\end{array}$ & $\begin{array}{c}\text { Reservoir } \\
\text { correction }^{\mathrm{a}} \\
\left({ }^{14} \mathrm{C} \mathrm{yr}\right)\end{array}$ & $\begin{array}{c}\text { error }^{a} \\
(1 \sigma)\end{array}$ & $\begin{array}{l}{ }^{14} \mathrm{C} \text { age } \\
\text { corrected for } \\
\text { reservoir }{ }^{\mathrm{b}} \\
\left({ }^{14} \mathrm{C} \text { yr BP }\right)\end{array}$ & $\begin{array}{c}\text { error }^{c} \\
(1 \sigma)\end{array}$ & $\begin{array}{c}\text { Calendar age } \\
\text { range }^{d} \\
(\operatorname{yr} B P, 2 \sigma)\end{array}$ & Ref. \\
\hline MD95-2002 & 0 & 0 & LSCE-99360 & G. bull & 2060 & 70 & 400 & 200 & 1660 & 212 & $1221-2061$ & 1 \\
\hline MD95-2002 & 140 & 140 & LSCE-99361 & G. bull & 9480 & 90 & 400 & 200 & 9080 & 219 & $9556-10761$ & 1 \\
\hline NGRIP-YD/PB & - & $195-205$ & - & - & - & - & - & - & - & - & $11555-11750$ & 2 \\
\hline MD95-2002 & 240 & 240 & LSCE-99362 & N. pch(s) & 11190 & 100 & 875 & 200 & 10315 & 224 & 11390 - 12664 & 1 \\
\hline MD03-2690 & 626 & $371-379$ & SacA-003234 & G. bull & 13020 & 60 & 680 & 200 & 12340 & 209 & $13793-15129$ & 3 \\
\hline NGRIP-GI1 & - & $380-390$ & - & - & - & - & - & - & - & - & $14460-14823$ & 2 \\
\hline MD03-2690 & 692 & $389-397$ & SacA-003235 & N. pch(s) & 13170 & 70 & 680 & 200 & 12490 & 212 & $13978-15367$ & 3 \\
\hline MD95-2002 & 420 & 420 & LSCE-99363 & N. $p c h(s)$ & 13730 & 130 & 970 & 200 & 12760 & 239 & $14227-15878$ & 1 \\
\hline MD95-2002 & 454 & 454 & LSCE-99364 & N. $p \operatorname{ch}(s)$ & 14200 & 110 & 970 & 200 & 13230 & 228 & $15234-16524$ & 1 \\
\hline MD95-2002 & 463 & 463 & LSCE-99365 & N. $p c h(s)$ & 14420 & 120 & 970 & 200 & 13450 & 233 & $15566-16946$ & 1 \\
\hline MD95-2002 & 510 & 510 & LSCE-99366 & N. $p c h(s)$ & 14570 & 130 & 970 & 200 & 13600 & 239 & $17771-17121$ & 1 \\
\hline MD95-2002 & 550 & 550 & SacA-003242 & N. $p c h(s)$ & 14830 & 70 & 970 & 200 & 13860 & 212 & $16215-17411$ & 3 \\
\hline MD95-2002 & 580 & 580 & Beta-141702 & N.pch(s) & 14810 & 200 & 970 & 200 & 13840 & 283 & $16027-17545$ & 1 \\
\hline MD95-2002 & 869 & 869 & SacA-003243 & N.pch(s) & 15300 & 70 & 400 & 200 & 14900 & 212 & $17653-18601$ & 3 \\
\hline MD95-2002 & 875 & 875 & SacA-003244 & N. $p c h(s)$ & 15280 & 160 & 400 & 200 & 14880 & 256 & $17547-18665$ & 3 \\
\hline MD03-2690 & 2923 & $1210-1216$ & SacA-005972 & G. bull & 17390 & 110 & 400 & 200 & 16990 & 228 & $19956-21082$ & 4 \\
\hline MD03-2692 & 580 & $1220-1225$ & SacA-001905 & G. bull & 17290 & 90 & 400 & 200 & 16890 & 219 & $19863-20933$ & 5 \\
\hline MD95-2002 & 1320 & 1320 & SacA-003245 & G. bull & 18850 & 90 & 400 & 200 & 18450 & 219 & $21826-22799$ & 3 \\
\hline MD95-2002 & 1340 & 1340 & SacA-003246 & G. bull & 19430 & 100 & 400 & 200 & 19030 & 224 & $22463-23471$ & 3 \\
\hline MD95-2002 & 1390 & 1390 & SacA-003247 & G. bull & 20620 & 80 & 400 & 200 & 20220 & 215 & $23827-24986^{e}$ & 3 \\
\hline NGRIP-GI2 & - & $1410-1415$ & - & - & - & - & - & - & - & - & $22706-23873$ & 6 \\
\hline MD95-2002 & 1424 & 1424 & Beta-123696 & N. pch(s) & 20240 & 60 & 400 & 200 & 19840 & 209 & $23397-24375$ & 7 \\
\hline MD95-2002 & 1453 & 1453 & Beta-123698 & N. $p c h(s)$ & 20430 & 80 & 400 & 200 & 20030 & 215 & $23547-24607$ & 7 \\
\hline MD95-2002 & 1464 & 1464 & Beta-123699 & N. pch(s) & 20600 & 80 & 400 & 200 & 20200 & 215 & $23799-24960$ & 7 \\
\hline MD95-2002 & 1534 & 1534 & Beta-123697 & N. $p c h(s)$ & 22250 & 70 & 400 & 200 & 21850 & 212 & 25737 - 26571 & 7 \\
\hline NGRIP-GI3 & - & $1590-1593$ & - & - & - & - & - & - & - & - & $26915-28544$ & 6 \\
\hline MD95-2002 & 1610 & 1610 & Beta-99367 & N. $p \operatorname{ch}(s)$ & 24410 & 250 & 400 & 200 & 24010 & 320 & 27614 - 28691 & 8 \\
\hline NGRIP-GI4 & - & 1635 & - & - & - & - & - & - & - & - & $27970-29729$ & 6 \\
\hline MD95-2002 & 1664 & 1664 & Beta-99368 & N.pch(s) & 25820 & 230 & 400 & 200 & 25420 & 305 & $28841-30385$ & 8 \\
\hline NGRIP-GI5 & - & 1795 & - & - & - & - & - & - & - & - & 31341 - 33558 & 6 \\
\hline NGRIP-GI6 & - & 1825 & - & - & - & - & - & - & - & - & $32503-34877$ & 6 \\
\hline NGRIP-GI7 & - & 1855 & - & - & - & - & - & - & - & - & 34137 - 36723 & 6 \\
\hline NGRIP-GI8 & - & 1895 & - & - & - & - & - & - & - & - & $36750-39590$ & 6 \\
\hline MD95-2002 & 1948 & 1948 & GifA-100123 & $N \cdot p \operatorname{ch}(s)$ & 34320 & 520 & 400 & 200 & 33920 & 557 & $36807-39644$ & 8 \\
\hline MD95-2002 & 1976 & 1976 & GifA-100124 & N. $p \operatorname{ch}(\mathrm{s})$ & 35480 & 520 & 400 & 200 & 35080 & 557 & $38583-40870$ & 8 \\
\hline
\end{tabular}

a: Reservoir correction infered from Stern et Lisieki (2013)

b: Corrected ${ }^{14} \mathrm{C}$ ages are obtained by subtracting the reservoir correction to the original ${ }^{14} \mathrm{C}$ age

c: Errors associated to the corrected ${ }^{14} \mathrm{C}$ were propagated through the quadratic sum

d: Corrected ${ }^{14} \mathrm{C}$ ages were then calibrated using the atmospheric calibration curve IntCal13 (Reimer et al., 2013)

e: ${ }^{14} \mathrm{C}$ age SacA-003247 was excluded from the age model since it is in clear age inversion 


\begin{tabular}{|c|c|c|c|c|c|c|c|c|c|c|}
\hline River & Country & $\begin{array}{l}\text { Drainage } \\
\text { surface } \\
\left(10.3 \mathrm{~km}^{2}\right)\end{array}$ & Lat. & Long. & $143 \mathrm{Nd} / 144 \mathrm{Nd}$ & \pm & 2se & $\varepsilon N d$ & \pm & $2 \mathrm{sd}$ \\
\hline \multicolumn{8}{|c|}{ British Isles - West (ISIS) } & $-10,8$ & \pm & 1,0 \\
\hline Shannon * & Ireland & 11,93 & 52.689 & -8.910 & 0,512130 & \pm & 12 & $-9,9$ & \pm & 0,3 \\
\hline Lee & Ireland & 1,08 & 51.878 & -8.266 & 0,512033 & \pm & 12 & $-11,8$ & \pm & 0,3 \\
\hline Severn & UK & 9,74 & 51.491 & -2.777 & 0,512026 & \pm & 11 & $-11,9$ & \pm & 0,3 \\
\hline \multicolumn{8}{|c|}{ British Isles - East UK (BIIS) } & $-11,6$ & \pm & 0,9 \\
\hline Humber & UK & 21,70 & 53.715 & -0.442 & 0,512083 & \pm & 6 & $-10,8$ & \pm & 0,3 \\
\hline Ouse & UK & 8,94 & 53.704 & -0.755 & 0,512013 & \pm & 13 & $-12,2$ & \pm & 0,3 \\
\hline Trent & UK & 10,75 & 53.657 & -0.696 & 0,511987 & \pm & 9 & $-12,7$ & \pm & 0,3 \\
\hline Hull & UK & 2,02 & 53.839 & -0.387 & 0,511985 & \pm & 7 & $-12,7$ & \pm & 0,3 \\
\hline \multicolumn{8}{|c|}{ English Channel (downstream part of Channel River) } & $-11,5$ & \pm & 1,3 \\
\hline Couesnon & France & 0,83 & 48.629 & -1.509 & 0,512061 & \pm & 5 & $-11,2$ & \pm & 0,3 \\
\hline Orne * & France & 2,24 & 49.133 & -0.401 & 0,512026 & \pm & 11 & $-11,9$ & \pm & 0,3 \\
\hline Seine * & France & 57,39 & 49.438 & 0.371 & 0,512009 & \pm & 9 & $-12,2$ & \pm & 0,3 \\
\hline Somme & France & 4,93 & 50.218 & 1.562 & 0,512242 & \pm & 13 & $-7,7$ & \pm & 0,3 \\
\hline Authie & France & 1,16 & 50.277 & 1.988 & 0,512030 & \pm & 6 & $-11,8$ & \pm & 0,3 \\
\hline Schelde & Belgium & 15,85 & 51.740 & 3.978 & 0,512056 & \pm & 15 & $-11,3$ & \pm & 0,3 \\
\hline Rhine * & Netherlands & 123,26 & 51.909 & 4.484 & 0,512033 & \pm & 13 & $-11,8$ & \pm & 0,3 \\
\hline Hamble & UK & 0,54 & 50.858 & -1.312 & 0,512019 & \pm & 12 & $-12,0$ & \pm & 0,3 \\
\hline Thames & UK & 11,52 & 51.511 & 0.099 & 0,512291 & \pm & 11 & $-6,7$ & \pm & 0,3 \\
\hline Colne & UK & 0,86 & 51.790 & 0.994 & 0,511996 & \pm & 13 & $-12,5$ & \pm & 0,3 \\
\hline \multicolumn{8}{|c|}{ North European Plain - West (southwestern SIS) } & $-11,4$ & \pm & 1,1 \\
\hline Ems & Germany & 13,20 & 53.231 & 7.405 & 0,512028 & \pm & 8 & $-11,9$ & \pm & 0,3 \\
\hline Weser * & Germany & 38,34 & 53.539 & 8.572 & 0,512178 & \pm & 9 & $-8,9$ & \pm & 0,3 \\
\hline Elbe * & Germany & 121,21 & 53.703 & 9.449 & 0,512058 & \pm & 9 & $-11,3$ & \pm & 0,3 \\
\hline Varde & Denmark & 1,12 & 55.632 & 8.507 & 0,512025 & \pm & 7 & $-11,9$ & \pm & 0,3 \\
\hline Oder & Germany & 101,49 & 53.841 & 14.121 & 0,512003 & \pm & 13 & $-12,4$ & \pm & 1,3 \\
\hline \multicolumn{8}{|c|}{ North European Plain - East (southeastern SIS) } & $-14,8$ & \pm & 0,7 \\
\hline Vistula * & Poland & 170,31 & 54.651 & 19.287 & 0,511903 & \pm & 11 & $-14,3$ & \pm & 0,3 \\
\hline Neman ** & Lithuania & 90,32 & 55.3620 & 21.257 & 0,511905 & \pm & 7 & $-14,3$ & \pm & 0,3 \\
\hline Daugava ** & Latvia & 90,44 & 57.060 & 24.039 & 0,511840 & \pm & 7 & $-15,5$ & \pm & 0,3 \\
\hline Gauja * & Latvia & 10,16 & 57.133 & 24.684 & 0,511911 & \pm & 7 & $-14,1$ & \pm & 0,3 \\
\hline Narva** & Estonia & 42,97 & 59.489 & 28.040 & 0,511795 & \pm & 11 & $-16,4$ & \pm & 0,3 \\
\hline \multicolumn{8}{|c|}{ North European Plain - West \& East (southern SIS) } & $-13,4$ & \pm & 1,9 \\
\hline \multicolumn{8}{|c|}{ Scandinavia (inner SIS) } & $-17,6$ & \pm & 1,7 \\
\hline Neva & Russia & 211,90 & 60.070 & 29.279 & 0,511728 & \pm & 11 & $-17,7$ & \pm & 0,3 \\
\hline Kymijoki * & Finland & 54,32 & 60.260 & 26.496 & 0,511679 & \pm & 9 & $-18,7$ & \pm & 0,3 \\
\hline Kiiminkijoki * & Finland & 7,46 & 65.133 & 25.731 & 0,511443 & \pm & 11 & $-23,3$ & \pm & 0,3 \\
\hline Luleälven & Sweden & 53,53 & 65.682 & 21.820 & 0,511657 & \pm & 6 & $-19,1$ & \pm & 0,3 \\
\hline Umeälven * & Sweden & 50,75 & 63.718 & 20.267 & 0,511716 & \pm & 7 & $-17,9$ & \pm & 0,3 \\
\hline Glomma * & Norway & 59,90 & 59.929 & 11.162 & 0,511929 & \pm & 8 & $-13,8$ & \pm & 0,3 \\
\hline
\end{tabular}

*: data from Freslon et al. (2014)

**: data from Soulet et al. (2013) 


\begin{tabular}{|c|c|c|c|c|c|c|c|c|c|c|}
\hline Site location & ID & Country & Lat. & Long. & Sedimentary environments \& Stratigraphy & Ref. & $143 \mathrm{Nd} / 144 \mathrm{Nd}$ & \pm 2 se & $\varepsilon N d$ & $\pm 2 \mathrm{sd}$ \\
\hline \multicolumn{9}{|c|}{ British Isles - Southern Ireland (ISIS) } & $-8,7$ & $\pm 4,6$ \\
\hline Whitting Bay East & WBE1 & Ireland & 51.949 & -7.766 & Muddy diamict (Irish Sea Till) & 1 & 0.512078 & \pm 7 & $-10,9$ & $\pm 0,3$ \\
\hline Ballycrooneen & BC1 & Ireland & 51.808 & -8.114 & Muddy diamict (Irish Sea Till) & 1 & 0.512045 & \pm 8 & $-11,5$ & $\pm 0,3$ \\
\hline Ardmore Bay & AB1 & Ireland & 51.973 & -7.698 & Muddy diamict (Irish Sea Till) & 1 & 0.512040 & \pm 9 & $-11,6$ & $\pm 0,3$ \\
\hline Kilmore Quay & KQE1 & Ireland & 52.167 & -6.6 & Muddy diamict (Irish Sea Till) & 1 & 0.512604 & \pm 14 & $-0,6$ & $\pm 0,3$ \\
\hline \multicolumn{9}{|c|}{ British Isles - Eastern Ireland (ISIS) } & $-12,5$ & $\pm 0,5$ \\
\hline Skerries & SK1 & Ireland & 53.58 & -6.105 & Muddy diamict (Irish Sea Till) & 2 & 0.512022 & \pm 7 & $-12,0$ & $\pm 0,3$ \\
\hline Killiney Bay & SPN1-2 & Ireland & 53.231 & -6.108 & Muddy diamict (Irish Sea Till) & 3 & 0.511971 & \pm 7 & $-13,0$ & $\pm 0,3$ \\
\hline \multicolumn{9}{|c|}{ British Isles - Southern \& Eastern Ireland (ISIS) } & $-11,8$ & $\pm 0,7$ \\
\hline \multicolumn{9}{|c|}{ British Isles - East UK (BIIS) } & $-13,1$ & $\pm 0,8$ \\
\hline Happisburgh & HPB1 & UK & 52.826 & 1.533 & Glaciolacustrine diamict (Anglian Stage) & 4 & 0.511996 & \pm 7 & $-12,5$ & $\pm 0,3$ \\
\hline Filey Bay & FLD1 & UK & 54.207 & -0.284 & Glaciolacustrine diamict (Filey Till, Filey lower Dms) & 5 & 0.511903 & \pm 5 & $-14,3$ & $\pm 0,3$ \\
\hline Filey Bay & FMD1 & UK & 54.207 & -0.284 & Glaciolacustrine diamict (Filey Till, Filey mid Dmm) & 5 & 0.511994 & \pm 6 & $-12,5$ & $\pm 0,3$ \\
\hline \multicolumn{9}{|c|}{ English Channel (downstream part of Channel River) } & $-11,8$ & $\pm 0,4$ \\
\hline English Channel & L1a-LV451 & UK & 50.643 & 0.098 & Periglacial slope (terrestrial), north of the Channel River & 6 & 0.512006 & \pm 6 & $-12,3$ & $\pm 0,3$ \\
\hline English Channel & N4c-LV403 & UK & 50.608 & 0.113 & Glaciofluvial (Northern Palaeovalley, Channel River) & 6 & 0.512028 & \pm 6 & $-11,9$ & $\pm 0,3$ \\
\hline English Channel & N4d-LV402 & UK & 50.608 & 0.114 & Glaciofluvial (Northern Palaeovalley, Channel River) & 6 & 0.512025 & \pm 5 & $-11,9$ & $\pm 0,3$ \\
\hline Fosse Dangeard & CM02-03 & France & 51.015 & 1.479 & Glaciolacustrine laminated silt & 7 & 0.512068 & \pm 7 & $-11,1$ & $\pm 0,3$ \\
\hline \multicolumn{9}{|c|}{ North Sea (confluence of BIIS and SIS) } & $-12,2$ & $\pm 1,5$ \\
\hline Dogger Bank & BGS1 & UK & 54.237 & 2.431 & Glacimarine sediment (Dogger Bank Fm) & 8 & 0.511983 & \pm 5 & $-12,7$ & $\pm 0,3$ \\
\hline Dogger Bank & BGS3 & UK & 54.245 & 2.183 & Glacimarine sediment (Dogger Bank Fm) & 8 & 0.511966 & \pm 6 & $-13,1$ & $\pm 0,3$ \\
\hline Dogger Bank & BGS6 & UK & 54.245 & 2.183 & Glacimarine sediment (Dogger Bank Fm) & 8 & 0.511953 & \pm 6 & $-13,3$ & $\pm 0,3$ \\
\hline Dogger Bank & BGS11 & UK & 54.966 & 2.633 & Glacimarine sediment (Dogger Bank Fm) & 8 & 0.512140 & \pm 9 & $-9,7$ & $\pm 0,3$ \\
\hline \multicolumn{9}{|c|}{ North European Plain - West (southwestern SIS) } & $-14,8$ & $\pm 1,3$ \\
\hline Knud Strand & KSS1 & Denmark & 56.658 & 8.777 & Glaciolacustrine (Spøttrup, Fegge Clay) & 9 & 0.511851 & \pm 6 & $-15,3$ & $\pm 0,3$ \\
\hline Rubjerg Knude & LKFm1 & Denmark & 57.450 & 9.778 & Glaciolacustrine (Lønstrup Klint Fm) & 10 & 0.511777 & \pm 6 & $-16,8$ & $\pm 0,3$ \\
\hline Rubjerg Knude & RKNFm1 & Denmark & 57.450 & 9.778 & Glaciofluvial, outwash plain (Rubjerg Knude Fm) & 10 & 0.511838 & \pm 8 & $-15,6$ & $\pm 0,3$ \\
\hline Rubjerg Knude & RIBFm1 & Denmark & 57.450 & 9.778 & Outwash plain (Ribjerg Fm) & 10 & 0.511850 & \pm 7 & $-15,3$ & $\pm 0,3$ \\
\hline Karup & KAR1 & Denmark & 56.312 & 9.185 & Outwash plain (Karup Sandur Fm) & 11 & 0.511969 & \pm 6 & $-13,0$ & $\pm 0,3$ \\
\hline Travemünde & S1 & Germany & 53.971 & 10.883 & Glaciolacustrine (Brodtener Ufer Cliff section) & 12 & 0.512001 & \pm 6 & $-12,4$ & $\pm 0,3$ \\
\hline Travemünde & S5 & Germany & 53.971 & 10.883 & Glaciolacustrine (Brodtener Ufer Cliff section) & 12 & 0.511910 & \pm 5 & $-14,2$ & $\pm 0,3$ \\
\hline Beelitz & BEE-a & Germany & 52.288 & 12.937 & Outwash plain; Glogow-Baruth IMV (Brandenburg IMP) & 13 & 0.511925 & \pm 5 & $-13,9$ & $\pm 0,3$ \\
\hline Beelitz & BEE-b & Germany & 52.288 & 12.937 & Outwash plain; Glogow-Baruth IMV (Brandenburg IMP) & 13 & 0.511929 & \pm 6 & $-13,8$ & $\pm 0,3$ \\
\hline Althüttendorf & ALT-a & Germany & 52.963 & 13.872 & Outwash plain; Torun-Eberswalde IMV (Pomeranian IMP) & 14 & 0.511790 & \pm 6 & $-16,5$ & $\pm 0,3$ \\
\hline Althüttendorf & ALT-b & Germany & 52.963 & 13.872 & Outwash plain; Torun-Eberswalde IMV (Pomeranian IMP) & 14 & 0.511830 & \pm 5 & $-15,7$ & $\pm 0,3$ \\
\hline Macherslust & MAC-a & Germany & 52.848 & 13.838 & Glaciolacustrine; Torun-Eberswalde IMV (Pomeranian IMP) & 14 & 0.511876 & \pm 3 & $-14,8$ & $\pm 0,3$ \\
\hline Macherslust & MAC-b & Germany & 52.848 & 13.838 & Glaciolacustrine; Torun-Eberswalde IMV (Pomeranian IMP) & 14 & 0.511837 & \pm 5 & $-15,6$ & $\pm 0,3$ \\
\hline \multicolumn{9}{|c|}{ North European Plain - East (southeastern SIS) } & $-15,1$ & $\pm 0,8$ \\
\hline Wypaleniska & WP1.1 & Poland & 53.059 & 18.144 & Vistula River erosional terrace (preceding the Leszno IA) & 15 & 0.511884 & \pm 6 & $-15,8$ & $\pm 0,3$ \\
\hline Wypaleniska & WP1.2 & Poland & 53.059 & 18.144 & Vistula River erosional terrace (preceding the Leszno IA) & 15 & 0.511913 & \pm 6 & $-14,7$ & $\pm 0,3$ \\
\hline Trzciniec & TRZ & Poland & 53.086 & 17.945 & Outwash plain; Torun-Eberswalde IMV (Pomeranian IMP) & 15 & 0.511913 & \pm 6 & $-14,1$ & $\pm 0,3$ \\
\hline Gorzen & GRZ & Poland & 53.133 & 17.729 & River terrace; Torun-Eberswalde IMV (Pomeranian IMP) & 15 & 0.511935 & \pm 6 & $-13,7$ & $\pm 0,3$ \\
\hline Oborki & OBK & Poland & 53.152 & 19.381 & Till, till plain (Poznan IA) & 16 & 0.511811 & \pm 6 & $-16,1$ & $\pm 0,3$ \\
\hline
\end{tabular}


Kozlowo

CHK1

Poland

CHK2

Poland

$\mathrm{ST} / 12$

Poland

$\mathrm{ST} / 13$

Poland

Karchowo

$\mathrm{ST} / 14$

Poland

Poland

Hetmanice

$\mathrm{ST} / 15$

Poland

Hetmanice
$53.341 \quad 18.341$ Till, till plain (Poznan IA)

53.535 19.904 Till, till plain (Poznan IA)

19.253 Diamict, ice marginal belt (Poznan IMP)

19.253 Diamict, ice marginal belt (Poznan IMP)

51.88916 .834 Outwash plain; Glogow-Baruth IMV (Leszno IMP)

51.88916 .834 Outwash plain; Glogow-Baruth IMV (Leszno IMP)

51.88916 .834 Outwash plain; Glogow-Baruth IMV (Leszno IMP)

51.858 16.265 Outwash plain; Glogow-Baruth IMV (Leszno IMP)

51.858 16.265 Outwash plain; Glogow-Baruth IMV (Leszno IMP)

51.858 16.265 Outwash plain; Glogow-Baruth IMV (Leszno IMP)
$0.511825 \pm 6 \quad-15,8 \quad \pm \quad 0,3$

$0.511827 \pm 6 \quad-15,8 \quad \pm 0,3$

$0.511894 \pm 6 \quad-14,5 \pm 0,3$

$0.511855 \pm 6-15,2 \pm 0,3$

$0.511820 \pm 4 \quad-15,9 \pm 0,3$

$0.511888 \pm 8 \quad-14,6 \pm 0,3$

$0.511844 \pm 4 \quad-15,4 \pm 0,3$

$0.511921 \pm 6 \quad-13,9 \pm 0,3$

$0.511792 \pm 4 \quad-16,5 \pm 0,3$

$0.511874 \pm 5 \quad-14,9 \quad \pm 0,3$

North European Plain - West \& East (southern SIS)

$-15,0 \pm 1,1$




\begin{tabular}{|c|c|c|c|c|}
\hline $\begin{array}{l}\text { Channel River } \\
\text { Runoff Events (R) }\end{array}$ & $\begin{array}{l}\text { start date } \\
\text { (cal ka BP) }\end{array}$ & $\begin{array}{l}\text { end date } \\
\text { (cal ka BP) }\end{array}$ & SIS Dynamic & $\begin{array}{l}\text { North Atlantic / Greenland } \\
\text { Climate Event }\end{array}$ \\
\hline & $16.7 \pm 0.2^{\mathrm{a}}$ & $15.7 \pm 0.3^{b}$ & Pomeranian ice advance & HS1 (second part = HE1) \\
\hline \multirow[t]{2}{*}{ R5 } & $18.2 \pm 0.2$ & $16.7 \pm 0.2$ & (subtantial) ice marginal retreat & HS1 (first part) \\
\hline & $18.7 \pm 0.3$ & $18.2 \pm 0.2$ & Frankfurt-Poznan ice advance & - \\
\hline \multirow[t]{2}{*}{$\mathrm{R} 4$} & $20.3 \pm 0.2$ & $18.7 \pm 0.3$ & (significant) ice marginal retreat & 19-ky MWP c \\
\hline & $21.3 \pm 0.2$ & $20.3 \pm 0.2$ & (Late) Brandenburg-Leszno ice advance & - \\
\hline \multirow[t]{2}{*}{ R3 } & $22.5 \pm 0.2$ & $21.3 \pm 0.2$ & (moderate) ice marginal retreat (onset deglaciation) & - \\
\hline & $23.4 \pm 0.3$ & $22.5 \pm 0.5$ & (Early) Brandenburg-Leszno ice advance (LGM) & - \\
\hline \multirow[t]{2}{*}{$\mathrm{R} 2$} & $25.7 \pm 0.3$ & $23.4 \pm 0.3$ & (moderate) ice marginal retreat & HS2 \\
\hline & $28.9 \pm 0.4$ & $25.7 \pm 0.3$ & ice advance (to LGM position) ${ }^{\mathrm{d}}$ & GI3-GI4 \\
\hline \multirow[t]{2}{*}{ R1 } & $30.7 \pm 0.7$ & $28.9 \pm 0.4$ & (moderate) ice marginal retreat & HS3 \\
\hline & $\sim 35^{\mathrm{e}}$ & $30.7 \pm 0.7$ & ice advance (onset Weichselian glaciation) e & GI5-GI6 ${ }^{\mathrm{f}}$ \\
\hline
\end{tabular}

a : this study; $17.2 \pm 0.4 \mathrm{ka}$ in Soulet et al. (2013)

b : Soulet et al. (2013) in good agreement with new exposure ages (Rinterknecht et al., 2012, 2013)

c : Carlson et Clark (2012), Clark et al. (2004), Yokoyama et al. (2000)

d: see Houmark-Nielsen (2003; Kattegat ice advance, Denmark) and Bradwell et al. (2008; North Sea)

e : see Bradwell et al. (2008; North Sea), Houmark-Nielsen et al. (2010; Klintholm ice advance, Denmark), Mangerud et al. (2010; Rogne Stadial, western Norway)

and Marks (2012; late Middle Vistulian, Poland) among others

$\mathrm{f}$ : see Mangerud et al. (2010) 


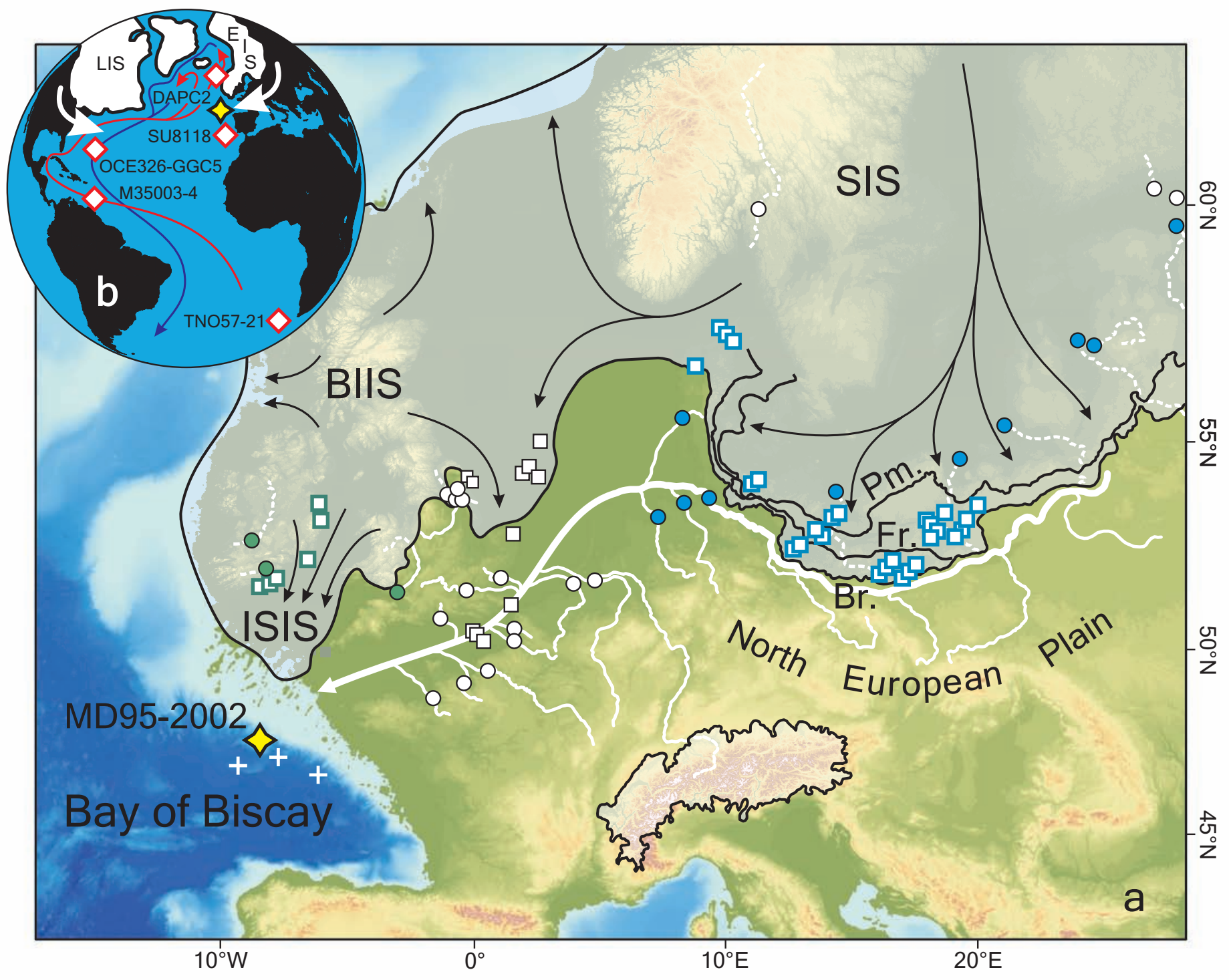


Depth MD95-2002 (m)
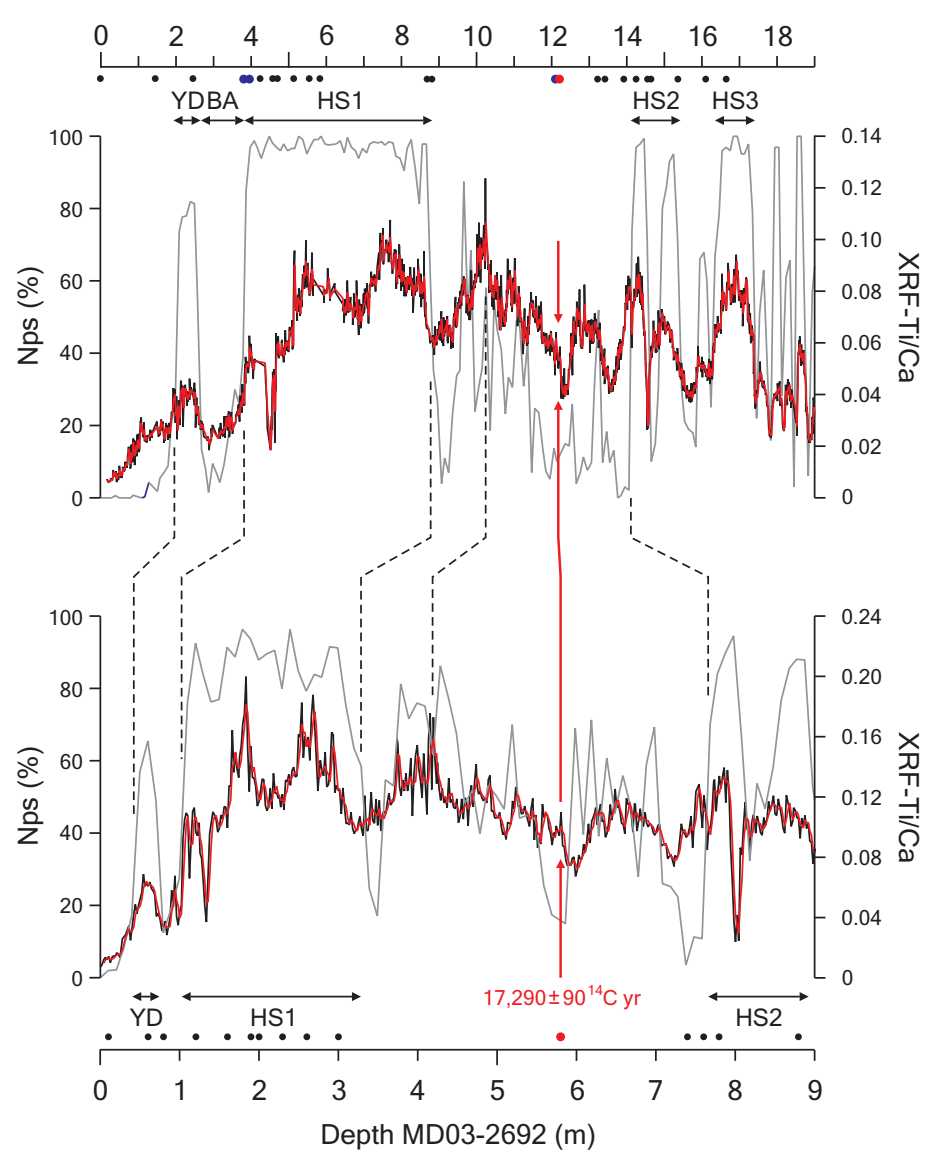

Depth MD95-2002 (m)

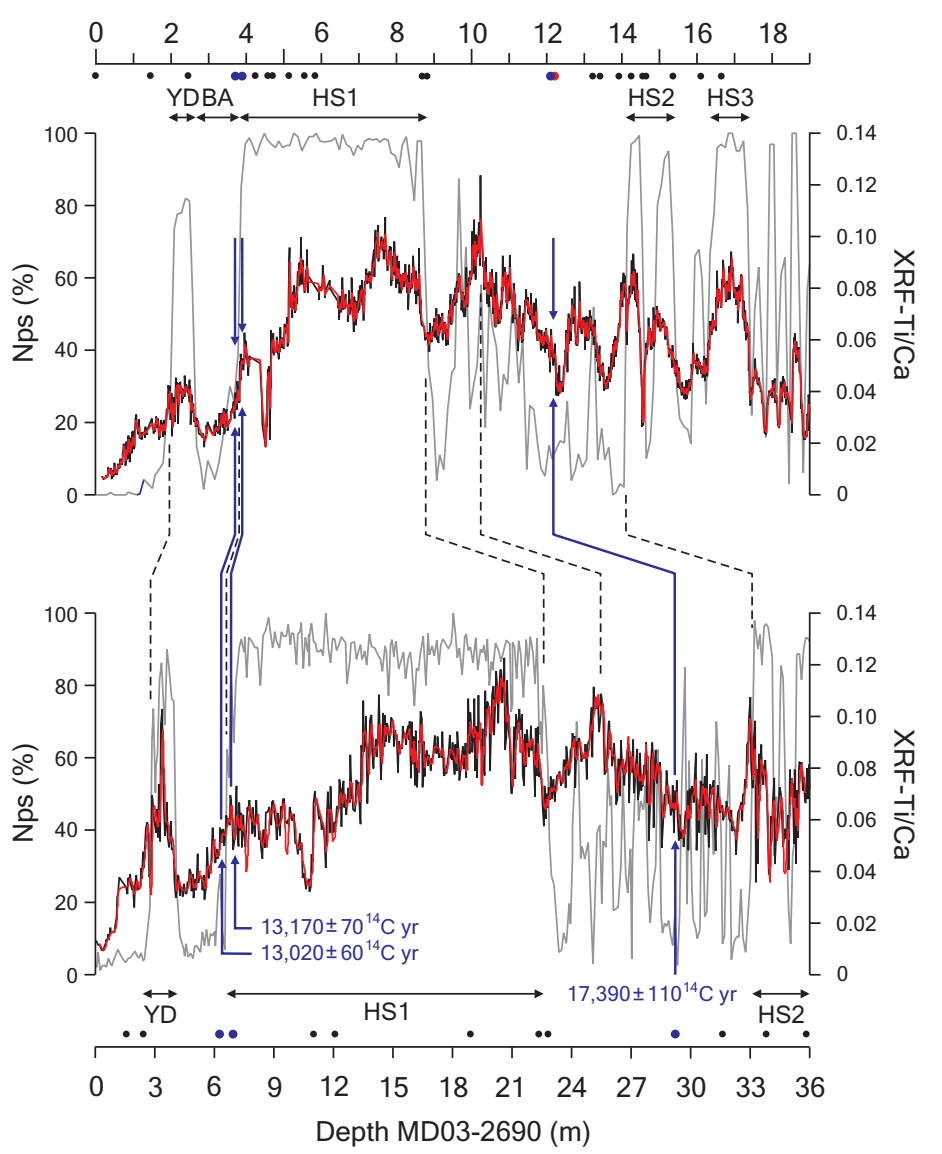




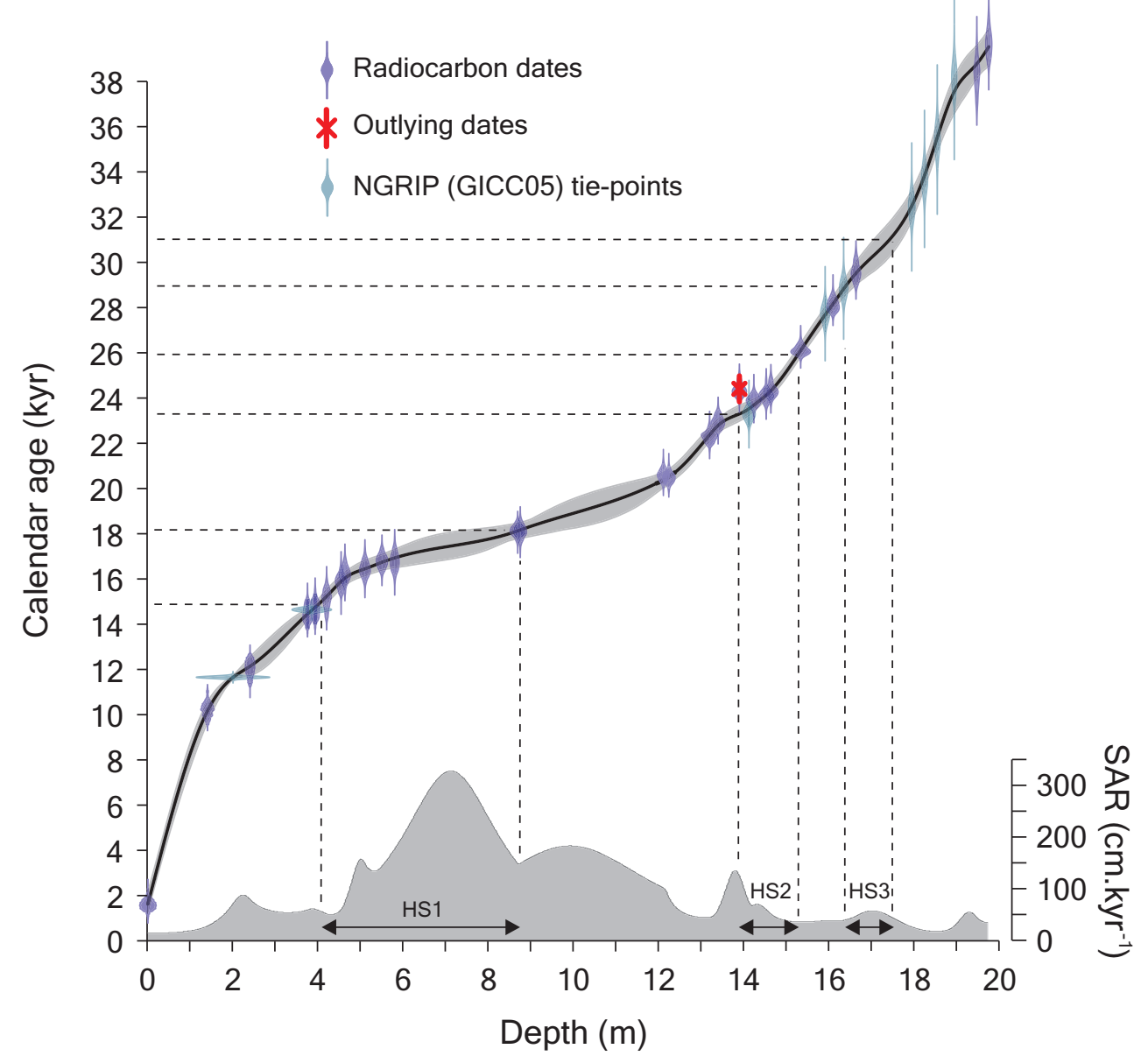




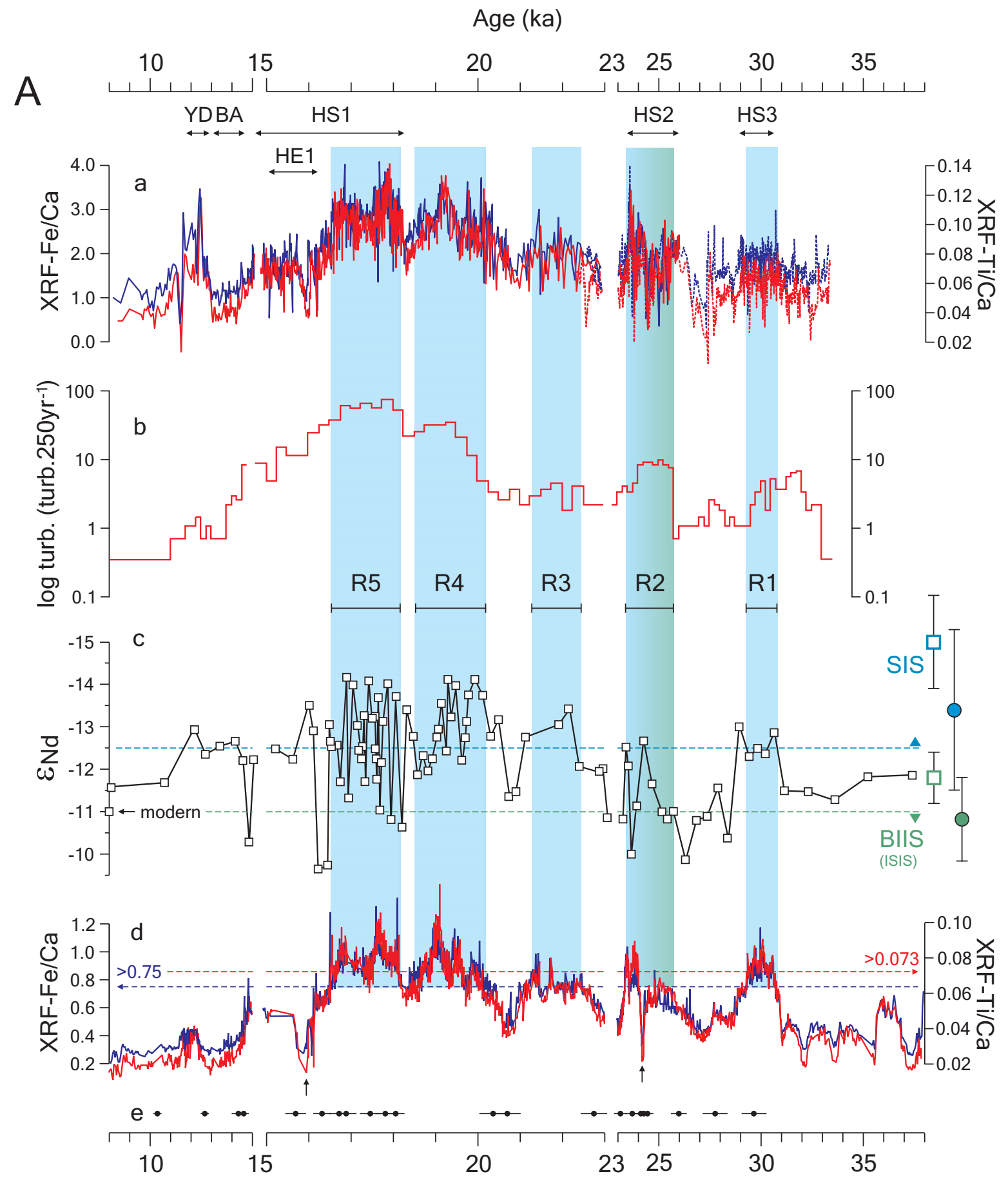

B Onset R5

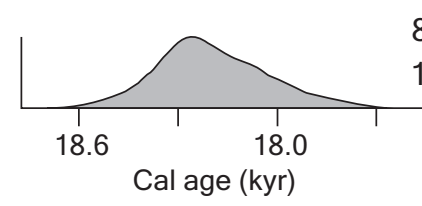

Onset R4

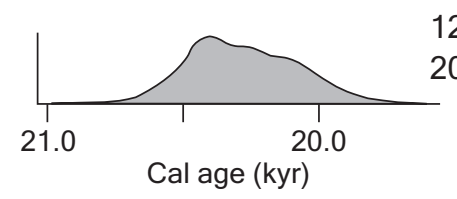

Onset R3

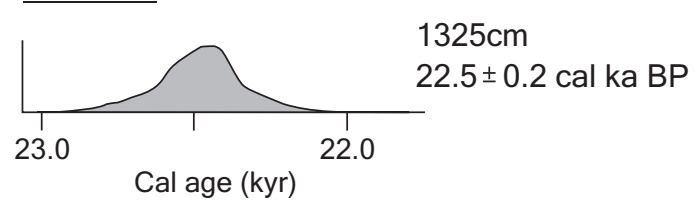

End R5

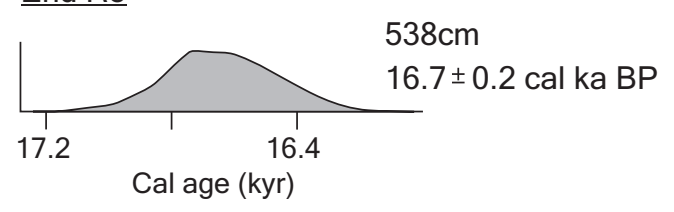

End R4

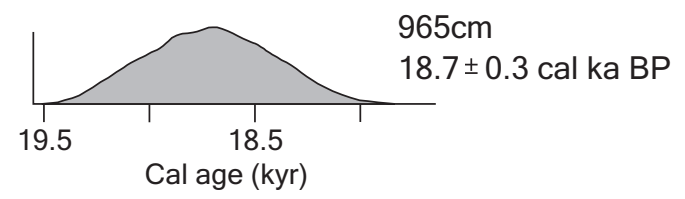

End R3

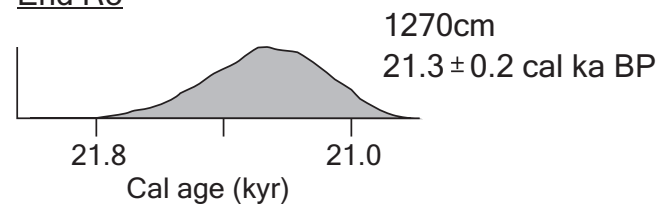



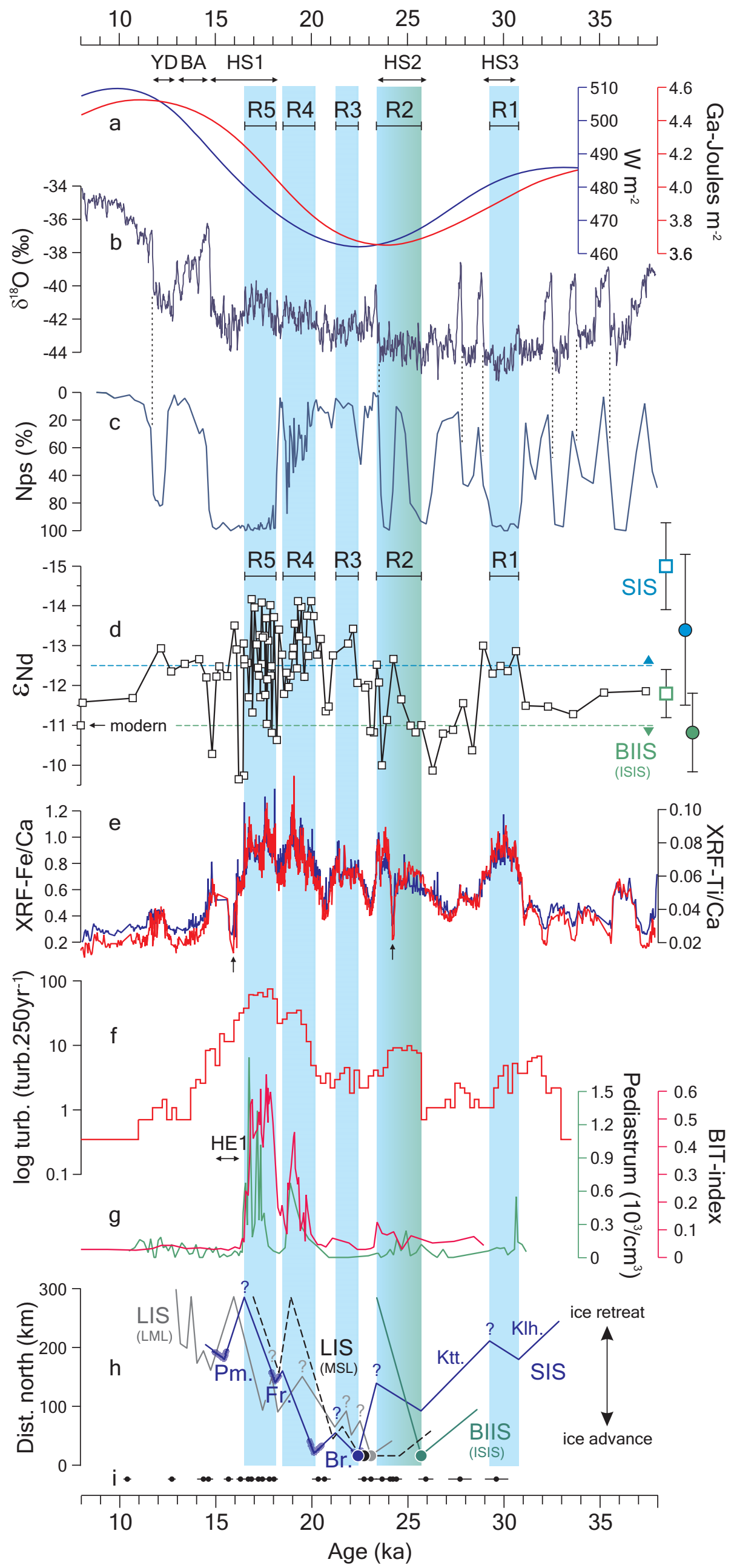
Longitude
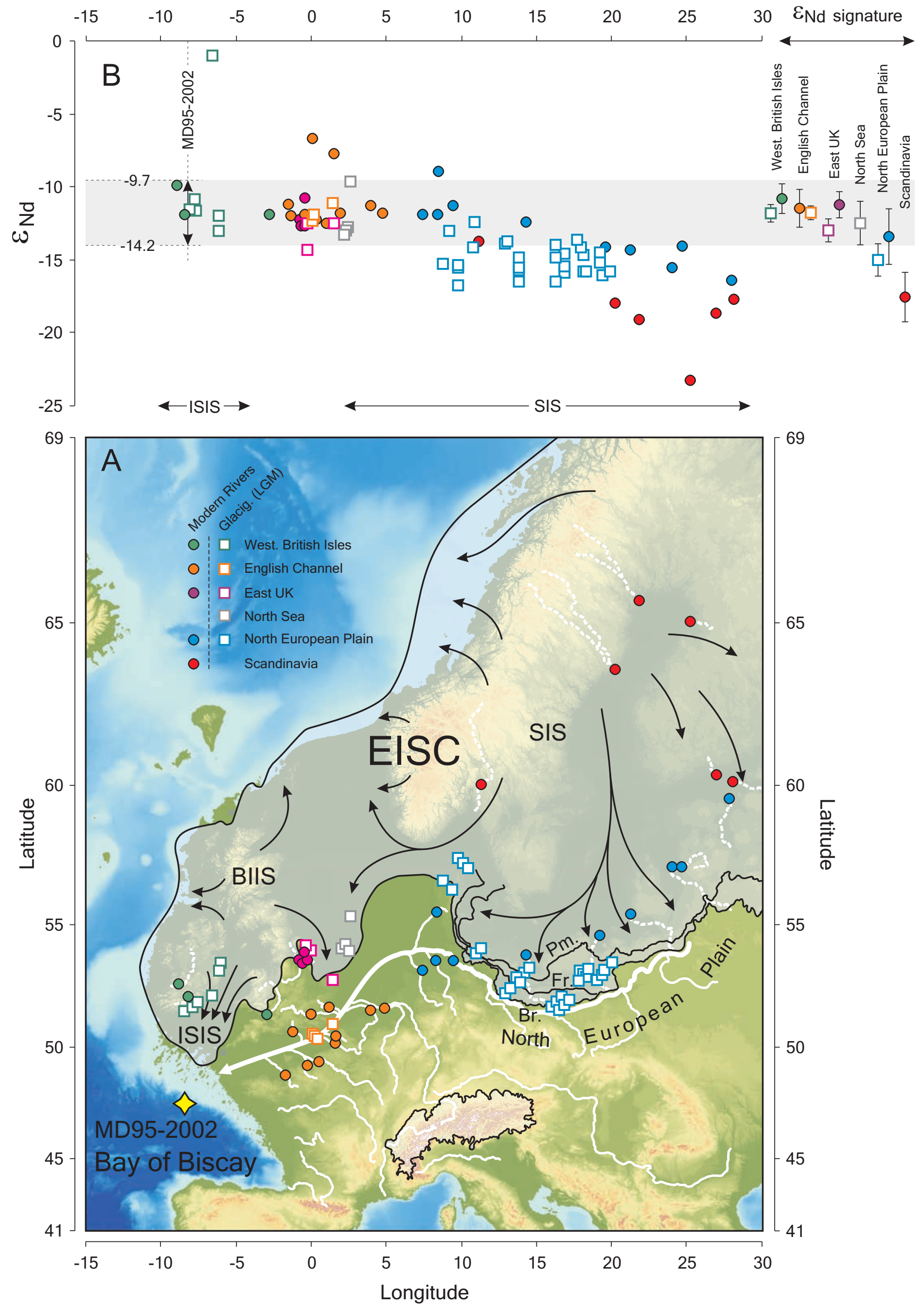


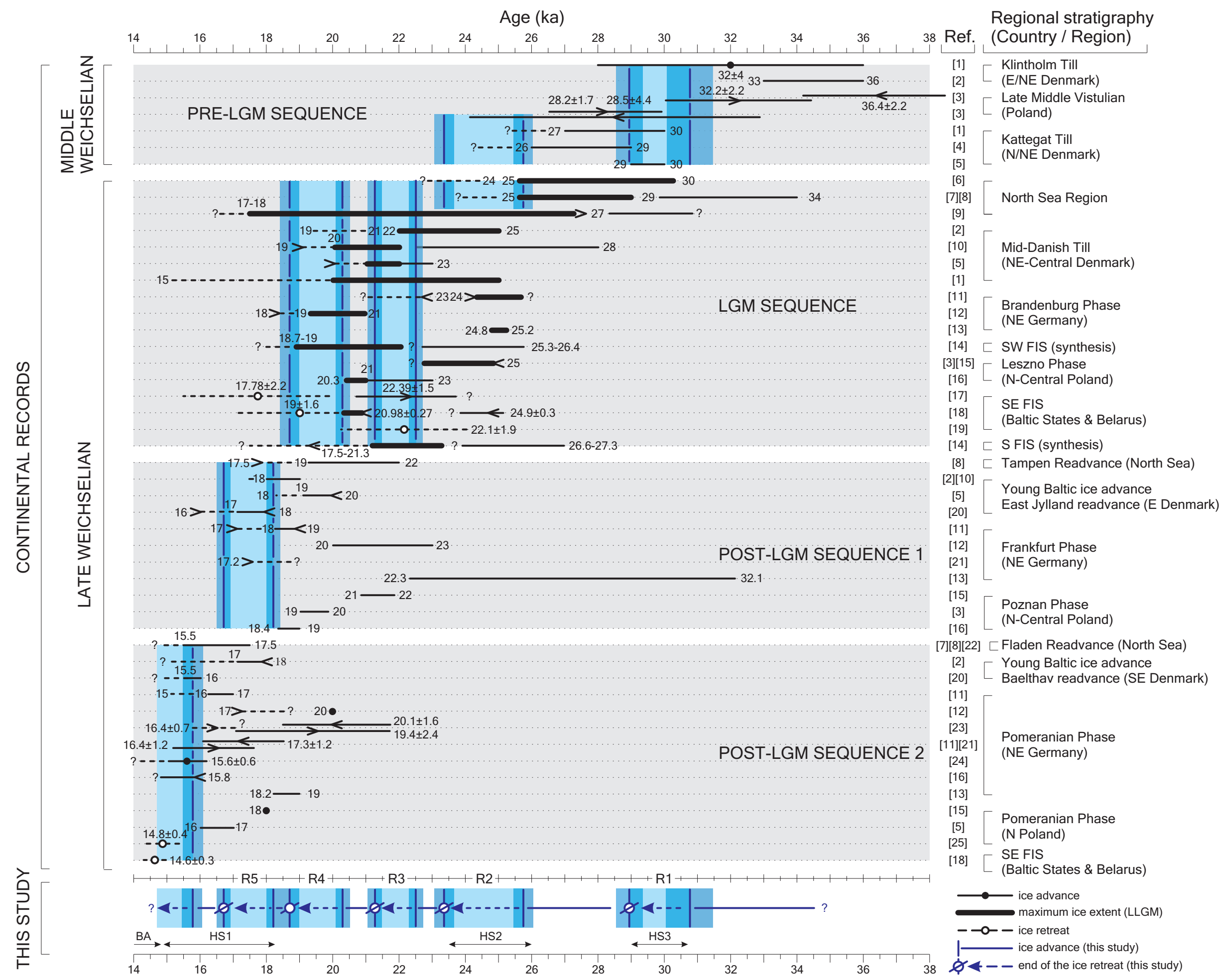

(Country/Region)

(N/NE Denmark)

North Sea Region

Mid-Danish Til

Brandenburg Phase

(NE Germany)

(Baltic States \& Belarus)

S FIS (synthesis)

Young Baltic ice advance

Poznan Phase

Fladen Readvance (North Sea)

Young Baltic ice advance

Pomeranian Phase

(NE Germany)

$156 \pm 0$

POST-LGM SEQUENCE 2

[ Pomeranian Phase

[25] (N Poland)

[ SE FIS 


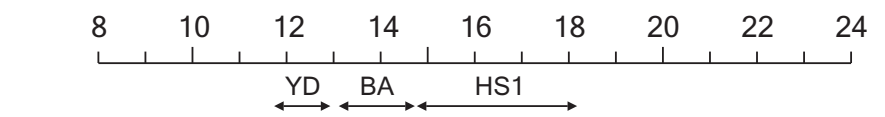
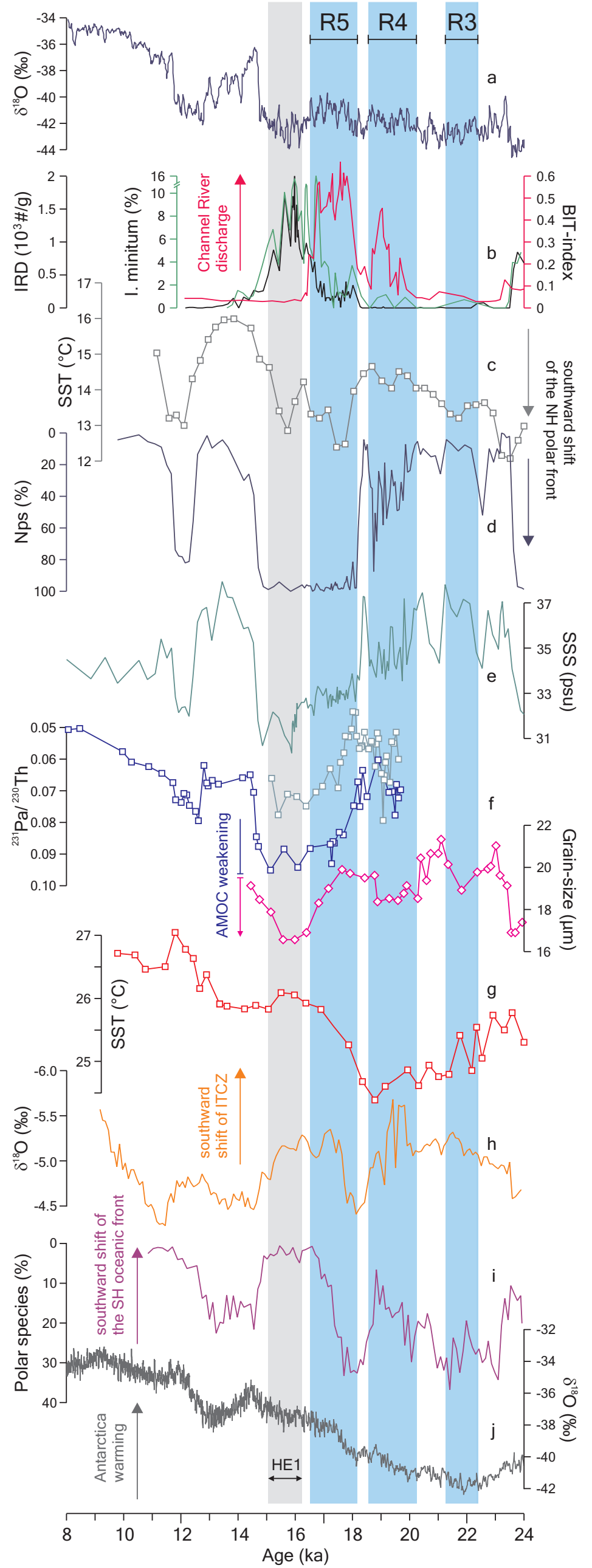
Supplementary Data
Click here to download Supplementary Data: SuppIMaterial.pdf

Supplementary Data
Click here to download Supplementary Data: SuppIMaterial.pdf Click here to download Supplementary Data: SuppiMaterialpdf

$(2+2$

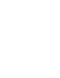
(

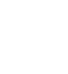
. (1) (1) (1) $\sqrt{3}$ (1) (1)

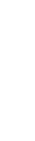
.

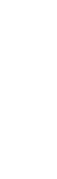

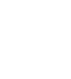
(1) (1) . . . . . . . . . . . . . . 